\title{
The Synergistic Evolution of Liberty and Equality in the Marriage Cases Brought by Same-Sex Couples in State Courts
}

Jean C. Love

Santa Clara University School of Law, jlove@scu.edu

Follow this and additional works at: http://digitalcommons.law.scu.edu/facpubs

Part of the Law Commons

\section{Recommended Citation}

13 J. Gender Race \& Just. 275

This Article is brought to you for free and open access by the Faculty Scholarship at Santa Clara Law Digital Commons. It has been accepted for inclusion in Faculty Publications by an authorized administrator of Santa Clara Law Digital Commons. For more information, please contact sculawlibrarian@gmail.com. 


\title{
1"int \\ Santa Clara University
}

\section{Santa Clara University School of Law}

\section{Legal Studies Research Papers Series}

Accepted Paper No. 10-04, April, 2010

The Synergistic Evolution of Liberty and Equality in the Marriage Cases Brought by Same-Sex Couples in State Courts

\author{
Jean C. Love \\ John A. and Elizabeth H. Sutro Professor of Law \\ Santa Clara University School of Law
}

This paper can be downloaded without charge from the Social Science Research Electronic Paper Collection:

http://ssrn.com/abstract=1596171 


\title{
The Synergistic Evolution of Liberty and Equality in the Marriage Cases Brought by Same-Sex Couples in State Courts
}

\author{
Jean C. Love* \\ I. INTRODUCTION
}

Legal scholars have expressed varying views about the role of liberty and equality in gay rights litigation. For example, in 1988, Professor Cass Sunstein took the position that the Due Process Clause is "backwardlooking,” protecting “traditional practices against short-run departures.” ${ }^{1}$ By contrast, he said that the Equal Protection Clause "looks forward, serving to invalidate practices that were widespread at the time of its ratification." ${ }^{2}$ Therefore, he encouraged gay rights litigators to lead with equality. In 2000, Professor William Eskridge challenged Sunstein's thesis. He examined the text and the history of the two clauses and concluded that both clauses are simultaneously present-looking, forward-looking, and backward-looking. ${ }^{3}$ Consequently, he took the position that the two clauses ought to be distinguished on the basis of their function. ${ }^{4}$ In the context of gay rights litigation, he suggested that plaintiffs' lawyers should rely first on the Due Process Clause (particularly in its more procedural aspects) for making disruptive challenges to statutes at the "retail level."5 Only later should they invoke "evolutive equal protection" for making broad facial challenges to statutes at the "wholesale level." ${ }^{6}$ More recently, Professor Kenji Yoshino encouraged gay rights litigators to lead with liberty on the theory that the recognition of liberty for all will serve to advance both liberty and equality. ${ }^{7}$ Finally, a fourth legal scholar, Professor Pamela Karlan, has suggested that

* John A. and Elizabeth H. Sutro Professor of Law, Santa Clara University. I dedicate this Article to my spouse, Patricia A. Cain.

1. Cass R. Sunstein, Sexual Orientation and the Constitution: A Note on the Relationship Between Due Process and Equal Protection, 55 U. CHI. L. REV. 1161, 1163, 1171 (2000).

2. Id. at 1163 .

3. William N. Eskridge, Destabilizing Due Process and Evolutive Equal Protection, 47 UCLA L. REV. 1183, 1185-86, 1218-19 (2000).

4. Id. at $1186-87$.

5. Id. at 1186 .

6. Id.

7. Kenji Yoshino, Tribe, 42 Tulsa L. Rev. 961, 969-70 (2007). 
"sometimes looking at an issue stereoscopically—-through the lenses of both the due process clause and the equal protection clause - can have synergistic effects, producing results that neither clause might reach by itself." ${ }^{8}$ In other words, Professor Karlan's theory would suggest that sometimes gay rights litigators ought to lead with both liberty and equality simultaneously.

This Article will examine selected marriage cases brought by same-sex couples in state courts in order to understand the role played by liberty and equality in this one segment of gay rights litigation. At first, neither liberty nor equality could dent the definition of marriage as an institution designed exclusively for opposite-sex couples. ${ }^{9}$ But gradually, over time, the interplay between the claims of liberty and equality began to alter the state courts' understanding of the institution of marriage ${ }^{10}$ It is the thesis of this Article (written with the benefit of 20/20 hindsight) that, by focusing on the two constitutional issues simultaneously, gay rights litigators in the state court marriage cases have sparked a synergistic evolution of both liberty and equality under state constitutional law.

This evolutionary process has not been linear. Instead, the courts have typically taken two steps forward ${ }^{11}$ and one step back. ${ }^{12}$ At times, the liberty claim and the equality claim have been in tension with one another. ${ }^{13} \mathrm{At}$ other times, the two claims have complemented each other. ${ }^{14}$ Yet, at all times, the interplay between the two claims has challenged the judiciary to rethink the fundamental question of whether marriage is an exclusive institution for opposite-sex couples only.

This Article will trace the synergistic evolution of liberty and equality in the state court marriage cases brought by same-sex couples. Its primary purpose is to demonstrate the effectiveness of advancing the two claims simultaneously when state constitutions are at issue. At the same time, gay rights litigators in federal court marriage equality cases ${ }^{15}$ may be interested in this Article as well because the assertion of the two claims simultaneously in the federal forum might spark a second, synergistic evolution of liberty and equality under the Federal Constitution.

Finally, a subsidiary purpose of this Article is to parse and compare the holdings in the key state court marriage equality cases in order to identify

8. Pamela Karlan, Equal Protection, Due Process, and the Stereoscopic Fourteenth Amendment, 33 MCGEORGE L. REV. 473, 474 (2002).

9. See, e.g., infra notes $17-33$ and accompanying text.

10. See, e.g., infra notes $47-60$ and accompanying text.

11. See, e.g., infra notes $154-236$ and accompanying text.

12. See, e.g., infra notes $237-307$ and accompanying text.

13. See, e.g., infra notes 34-89 and accompanying text.

14. See, e.g., infra notes 308-59 and accompanying text.

15. E.g., Perry v. Schwarzenegger, No. CV09-2292 (N.D. Cal. filed May 22, 2009), available at http://www.equalrightsfoundation.org/legal-filings/plaintiffs-filed-complaint/. 
each step in the process by which the courts gradually moved toward the extension of marriage to same-sex couples. Parsing and comparing the holdings is complicated by the fact that there is a split of opinion among the justices in most of the cases under review. The phenomenon of fractured courts in the state court marriage cases finally came to an end when the Iowa Supreme Court issued a unanimous opinion extending marriage to same-sex couples in Varnum v. Brien. ${ }^{16}$

\section{BAKER V. NELSON: LIBERTY AND EQUALITY WITH NO SYNERGY}

In the first marriage equality case, Baker v. Nelson, ${ }^{17}$ a male couple claimed in state court that Minnesota's opposite-sex marriage statute denied the plaintiffs both liberty and equality under the Federal Constitution. More specifically, the plaintiffs asserted that "the right to marry without regard to the sex of the parties is a fundamental right of all persons," and that "restricting marriage to only couples of the opposite sex is irrational and invidiously discriminatory." ${ }^{18}$ In essence, the plaintiffs were asking the court to look at the marriage issue stereoscopically. They were challenging the sex-based classification in the marriage statute as a denial of equal protection, and simultaneously, they were inviting the court to broaden the scope of the fundamental right to marry by defining that liberty interest without regard to the sex of the parties. The plaintiffs were basing their claim upon Loving v. Virginia, ${ }^{19}$ a case that the United States Supreme Court had decided three years earlier, in which the Court struck down Virginia's anti-miscegenation statute under both the Due Process and the Equal Protection Clauses of the Federal Constitution.

With regard to liberty, the Court in Loving declared: "The freedom to marry has long been recognized as one of the vital personal rights essential to the orderly pursuit of happiness by free men." 20 The Court further recognized the freedom to marry as the right to marry a person of one's choice, and the Court characterized marriage as one of the "basic civil rights of man." ${ }^{21}$ But when the plaintiffs in Baker v. Nelson asserted that they had a fundamental right to marry, the Minnesota Supreme Court balked. ${ }^{22}$ It ignored the definition of marriage in Loving and relied instead on a very traditional definition of marriage: "The institution of marriage, as a union of man and woman, uniquely involving the procreation and rearing of children

\footnotetext{
16. Varnum v. Brien, 763 N.W.2d 862 (Iowa 2009).

17. Baker v. Nelson, 191 N.W.2d 185 (Minn. 1971).

18. Id. at 186.

19. Loving v. Virginia, 388 U.S. 1 (1967).

20. Id. at 12 .

21. Id.

22. Baker v. Nelson, 191 N.W.2d at 186.
} 
within a family, is as old as the book of Genesis."23 Because the plaintiffs (as a couple) could not procreate, the court rejected their liberty claim outright, emphasizing that the Due Process Clause is "not a charter for restructuring [marriage] by judicial legislation." ${ }^{24}$

With regard to equality, the Court in Loving applied strict scrutiny to strike down a race-based classification. ${ }^{25}$ Yet, when the plaintiffs in Baker $v$. Nelson alleged that the Minnesota statute contained a sex-based classification that also ought to be stricken under the Equal Protection Clause, the Minnesota Supreme Court once again balked. ${ }^{26}$ The court accepted the plaintiffs' assertion that the statute contained a facial sex-based classification, but it applied deferential low-level scrutiny and held that there was "no irrational or invidious discrimination."27

The plaintiffs contended that the means were in fact not rationally related to the State's objective of promoting procreation because the statute did not require opposite-sex couples to prove their capacity and willingness to procreate as a condition of obtaining a marriage license. ${ }^{28}$ The court responded that “'abstract symmetry' is not demanded by the Fourteenth Amendment." 29 In a footnote, the court further observed that the Equal Protection Clause "does not require things which are different in fact or opinion to be treated in law as though they were the same." 30 The court thereby suggested that same-sex couples are not similarly situated to opposite-sex couples for purposes of marriage under the Equal Protection Clause because they are unable to procreate. The court then distinguished Loving on the ground that "in commonsense and in a constitutional sense, there is a clear distinction between a marital restriction based merely upon race and one based upon the fundamental difference in sex.”31

The Minnesota Supreme Court held that the opposite-sex marriage statute did not violate the Federal Constitution. ${ }^{32}$ The United States Supreme Court dismissed the plaintiffs' appeal for want of a substantial federal question. ${ }^{33}$ In the beginning, then, the ability to procreate defined the scope of the right to marry, and the inability of same-sex couples to procreate

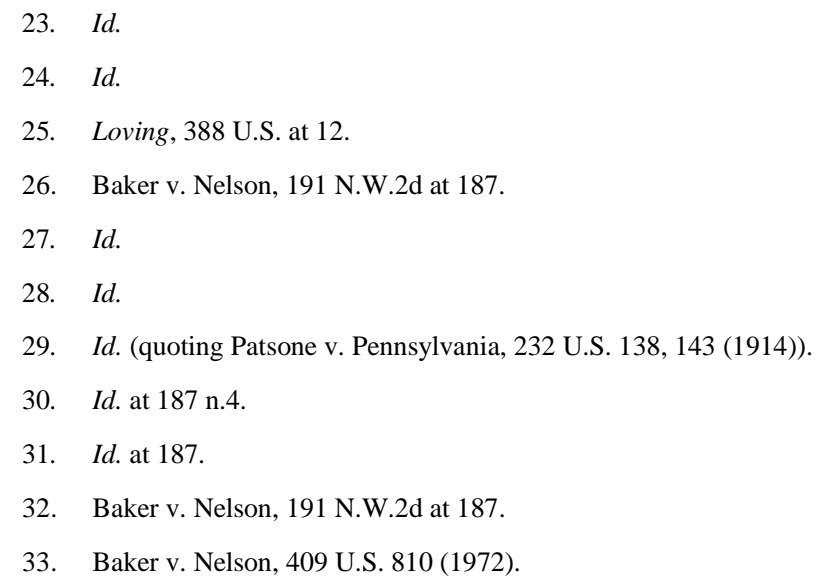


justified their exclusion from the institution of marriage under the Equal Protection Clause. Neither a liberty claim nor an equality claim was strong enough to overcome the power of the traditional definition of marriage, and advancing the two claims simultaneously sparked absolutely no synergy whatsoever.

\section{BAEHR V. LEWIN: LIBERTY AND EQUALITY WITH A HINT OF SYNERGY}

When same-sex couples renewed their commitment to the fight for marriage equality two decades later, they sought to avoid the adverse impact of Baker v. Nelson ${ }^{34}$ by filing their complaints in state courts and alleging violations of state constitutions. In the first such case, Baehr v. Lewin, ${ }^{35}$ the plaintiffs (three same-sex couples) alleged a denial of both liberty and equality under the Hawaii Constitution. ${ }^{36}$ The Hawaii Supreme Court had a tradition of looking first to federal law when interpreting the state constitution, but it also was willing to construe the state constitution independently of the Federal Constitution. ${ }^{37}$

With regard to the liberty claim in Baehr, the plaintiffs asked the court to recognize a "new fundamental right," namely, "a right to same-sex marriage." 38 Unfortunately for the plaintiffs, the court chose to construe the State's due process clause in accord with the Federal Constitution. ${ }^{39}$ Moreover, the court chose to interpret the Federal Constitution in keeping with Professor Sunstein's theory that the Due Process Clause is "backwardlooking," protecting fundamental rights that are rooted in tradition. ${ }^{40}$ When the court examined the relevant United States Supreme Court opinions, ${ }^{41}$ it found a "link" between the right to marry and the right to procreate. ${ }^{42}$ Consequently, the court concluded that the "federal construct of the fundamental right to marry ... presently contemplates unions between men and women." 43 Turning to the issue before it, the court said that the question was "whether we will hold that same-sex couples possess a fundamental

34. Baker v. Nelson, 191 N.W.2d 185 (Minn. 1971), appeal dismissed for want of a substantial federal question, 409 U.S. 810 (1972).
35. Baehr v. Lewin, 852 P.2d 44 (Haw. 1993).
36. Id. at 50 .
37. Id. at 57.
38. Id.
39. Id. at 55.
40. See Sunstein, supra note 1.
41. Baehr, 852 P.2d at 55-56.
42. Id. at 56 .
43. Id. 
right to marry." ${ }^{44}$ Not surprisingly, given the framing of the issue, the court rejected the plaintiffs' liberty claim outright for the following reasons:

[W]e do not believe that a right to same-sex marriage is so rooted in the traditions and collective conscience of our people that failure to recognize it would violate the fundamental principles of liberty and justice that lie at the base of all our civil and political institutions. Neither do we believe that a right to same-sex marriage is implicit in the concept of ordered liberty, such that neither liberty nor justice would exist if it were sacrificed. ${ }^{45}$

Accordingly, the court ruled that the plaintiffs did not have a fundamental constitutional right to same-sex marriage under the due process clause of the state constitution. ${ }^{46}$

With regard to the equality claim, the plaintiffs asked the court to rule that the State's ban on same-sex marriage violated Hawaii's equal protection clause, which provides in relevant part: "No person shall . . . be denied equal protection of the laws, nor be denied the enjoyment of the person's civil rights . . because of race, religion, sex or ancestry." 47 Fortunately for the plaintiffs, the court chose to construe the State's equal protection clause independently of the Federal Constitution on the ground that the text of the State's equal protection clause is not a mirror image of the Federal Constitution. ${ }^{48}$ Moreover, the court chose to construe the state constitution in accord with Professor Sunstein's theory that an equal protection clause is generally forward-looking. ${ }^{49}$

The first question that arose under the State's equal protection clause was whether marriage is a civil right. ${ }^{50}$ After consulting a dictionary, a plurality of the court (later to become a majority) announced that "civil rights" are "civil liberties," which in turn may be defined as "[p]ersonal, natural rights guaranteed and protected by the Constitution." 51 The plurality then held that marriage is a civil right. ${ }^{52}$ The plurality supported its holding by quoting the following sentence from the due process section of Loving $v$.

\footnotetext{
44. Id. at 57 .

45. Id.

46. Id.

47. HAW. CONST. art. I, § 5 .

48. Baehr, 852 P.2d at 59 .

49. That is, through an equality claim, a disadvantaged group may ask a court to examine the effect of a traditional practice (such as opposite-sex marriage) and eliminate the adverse impact of that traditional practice on currently disadvantaged groups (such as same-sex couples). See supra note 2 and accompanying text.
}
50. Baehr, 852 P.2d at 60 .
51. Id.
52. Id. 
Virginia: ${ }^{53}$ “"The freedom to marry has long been recognized as one of the vital personal rights essential to the orderly pursuit of happiness by free [people]." "54 The plurality went on to say: "So 'fundamental' does the United States Supreme Court consider the institution of marriage that it has deemed marriage to be 'one of the "basic civil rights of [men and women].,",55

The two dissenting judges, who had joined the plurality in rejecting the plaintiffs' liberty claim, criticized the plurality for ruling that there is a " "civil right' to a same sex marriage" under the State's equal protection clause. ${ }^{56}$ From the dissenters' point of view, the plurality's ruling was inconsistent with the court's holding that there was no fundamental right to same-sex marriage under the State's due process clause. ${ }^{57}$ The plurality responded by saying that it had "not held" that the plaintiffs "have a 'civil right' to a same sex marriage," but rather, it had simply "noted that the United States Supreme Court has recognized for over fifty years that marriage is a basic civil right." 58 From the plurality's standpoint, the Supreme Court's recognition that marriage is a civil right was at least "relevant" to a proper interpretation of the State's equal protection clause. ${ }^{59}$

This is the moment when one can begin to see a hint of the synergistic evolution of liberty and equality in Baehr. Even though the Hawaii Supreme Court was not willing to hold that the plaintiffs had a fundamental right to same-sex marriage under the State's due process clause, the plurality was willing to find that marriage is a "civil right" under the State's equal protection clause. ${ }^{60}$ The plurality took the concept that marriage is a "civil right" directly from the United States Supreme Court's discussion of "liberty" in Loving. Linguistically, defining marriage as a "civil right" for purposes of the equal protection clause permitted the plurality to shift its focus from the "link" between marriage and procreation to the "link" between marriage and the pursuit of happiness.

The second question under Hawaii's equal protection clause was whether the opposite-sex marriage statute denied the plaintiffs the enjoyment of the civil right of marriage because of sex. The plaintiffs had alleged, and the defendant's amended answer had admitted, that the State denied the plaintiffs' applications for marriage licenses on the ground that "each couple

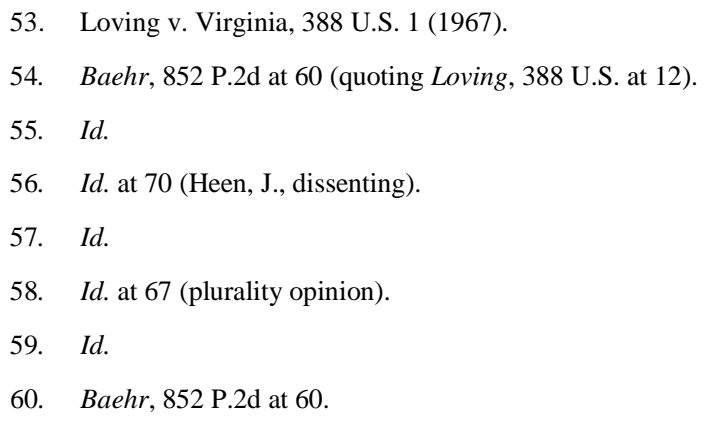


was of the same sex." ${ }^{61}$ Based on these pleadings, the plurality took the position that the statute, both "on its face" and "as applied," regulated access to the status of marriage on the basis of the applicant's sex. ${ }^{62}$

The dissenting judges chose to focus not on the defendant's amended answer, but rather on his answering brief, with which they agreed. ${ }^{63}$ The defendant's answering brief took the position that the plaintiffs were not denied marriage licenses "because of their sex," but rather because of their "biologic inability as a couple to satisfy the definition of the status to which they aspire." 64 Put another way, the defendant argued that "the right of persons of the same sex to marry one another does not exist because marriage, by definition and usage, means a special relationship between a man and a woman." 65 In effect, the defendant contended that same-sex couples are not similarly situated to opposite-sex couples for purposes of marriage because they are unable to procreate. The plurality rejected the defendant's argument on the grounds that it was not only "circular and unpersuasive," 66 but also an "exercise in tortured and conclusory sophistry." ${ }^{67}$ The plurality was able to dismiss the defendant's argument so decisively because it had held that marriage is a "civil right," thereby linking marriage to the pursuit of happiness (rather than to procreation) ${ }^{68}$

The concurring judge thought that the statute, which distinguished between "same-sex couples" and "opposite-sex couples," might be found to contain a sexual orientation-based classification that would be the equivalent of a sex-based classification (provided the plaintiffs could submit proof at trial that sexual orientation is "biologically fated"). ${ }^{69}$ The plurality disagreed because it opined that denying marriage licenses to same-sex couples was not the same as denying marriage licenses to homosexuals. ${ }^{70}$ Furthermore, the plurality took the position that the statute did not contain a facial sexual orientation-based classification. ${ }^{71}$ The plurality based its position on the following line of reasoning: "Parties to 'a union between a man and a woman' may or may not be homosexuals. Parties to a same-sex marriage
61. Id. at 50 .
62. Id. at 60 .
63. Id. at 70-71, 73 (Heen, J., dissenting).
64. Id. at 60-61 (plurality opinion).
65. Id. at 61 .
66. Baehr, 852 P.2d at 61.
67. Id. at 63 .
68. See supra notes 50-55 and accompanying text.
69. Baehr, 852 P.2d at 69-70 (Burns, J., concurring).
70. Id. at $52 \mathrm{n} .11$ (plurality opinion).
71. Id. 
could theoretically be either homosexuals or heterosexuals."72 The two dissenting judges agreed with the plurality that the text of the statute did not facially discriminate on the basis of sexual orientation.

The dissenters also took the position that the text of the statute did not facially discriminate on the basis of sex because it applied equally to both men and women. ${ }^{73}$ Women could not marry women, and men could not marry men. ${ }^{74}$ In other words, the dissenting judges would have recognized the equal application defense. ${ }^{75}$ The plurality disagreed, taking the position that Loving expressly rejected the equal application defense in the context of a challenge to an anti-miscegenation statute containing a race-based classification. Consequently, the plurality concluded by way of analogy that it was free to reject the equal application defense in the context of a challenge to an opposite-sex marriage statute containing a sex-based classification. ${ }^{76}$

The plurality knew that, under the Federal Equal Protection Clause, sexbased classifications are subject to intermediate-level scrutiny. ${ }^{77}$ But Hawaii's equal rights amendment provides: "Equality of rights under the law shall not be denied or abridged by the State on account of sex." "78 Therefore, the issue before the court was whether the equal rights amendment required the application of intermediate-level scrutiny or strict scrutiny to a sex-based classification. The plurality ruled: "In light of ... the presence of article I, section 3-the Equal Rights Amendment-in the Hawaii Constitution, ... . we hold that sex is a 'suspect category' for purposes of equal protection analysis under article I, section $5 \ldots$ and that [the marriage statute] is subject to the 'strict scrutiny' test."79

The Hawaii Supreme Court reversed the trial court's judgment for the defendant on the pleadings and remanded the case to the trial court for further proceedings consistent with the plurality opinion. ${ }^{80}$ The defendant moved for reconsideration or clarification because the court had split

72. Id.

73. Id. at 71 (Heen, J., dissenting).

74. Id.

75. Baehr, 852 P.2d at 72 .

76. Id. at 68 (plurality opinion).

77. Id. at 64 (citing Craig v. Boren, 429 U.S. 190 (1976)).

78. HAW. CONST. art. I, § 3.

79. Baehr, 852 P.2d at 67. Earlier cases in Hawaii had avoided the issue of whether "sex" should be treated as a "suspect classification" under the state constitution. See, e.g., Holdman v. Olim, 581 P.2d 1164, 1168 (Haw. 1978) (holding that the court did not need to reach the issue of whether sex was a suspect category because a prison rule requiring female visitors to wear brassieres would have satisfied the compelling state interest test under strict scrutiny).

80. Baehr, 852 P.2d at 68 . 
regarding its interpretation of the equal protection clause. ${ }^{81}$ At the time of the hearing on the defendant's motion, one of the two dissenting judges had been replaced by a judge who was willing to support the plurality opinion. ${ }^{82}$ This change in the composition of the court effectively turned the plurality opinion into a majority opinion.

On remand, the trial court applied strict scrutiny to the sex-based classification. ${ }^{83}$ It found that the statute was unconstitutional because the State had "failed to present sufficient credible evidence which demonstrates that the public interest in the well-being of children and families ... would be adversely affected by same-sex marriage." 84 The trial court then issued an injunction prohibiting the State from denying an application for a marriage license solely because the applicants were of the same sex. ${ }^{85}$

The State obtained a stay of the injunction pending its appeal of the case. ${ }^{86}$ Before the Hawaii Supreme Court could consider that appeal, however, the people of Hawaii voted to adopt a constitutional amendment that gave the legislature the exclusive authority to define marriage in the State of Hawaii. ${ }^{87}$ The legislature chose to define marriage as a union between one man and one woman. ${ }^{88}$ Thus, within the context of a single case, the evolution of marriage equality had moved two steps forward and one giant step back.

Baehr is a case in which there was an incredible tension between the liberty claim and the equality claim. Under the "backward-looking" liberty theory, the Hawaii Supreme Court (like the Minnesota Supreme Court in Baker v. Nelson) found that the fundamental right to marry under the Federal Constitution was inextricably linked to the right to procreate. Because the court chose to construe the state constitutional right to liberty in accord with the Federal Constitution, the plaintiffs could not mount a successful challenge to the marriage statute under the State's due process clause.

When the Hawaii Supreme Court turned its attention to the unique text of the State's equal protection clause (prohibiting the denial of "civil rights" on the basis of sex), the court chose to construe the state constitution

81. Id. at 74 (2-1-2 decision).

82. Id. at 74-75. See also Nancy Klingeman \& Kenneth May, Recent Development, For Better or for Worse, in Sickness and in Health, Until Death Do Us Part: A Look at Same-Sex Marriage in Hawaii, 16 U. HAW. L. REV. 447, 480 (1994).

83. Baehr v. Miike, No. 91-1394, 1996 WL 694235, at *19 (Haw. Cir. Ct. Dec. 3, 1996).

84. Id. at $* 21$.

85. Id. at $* 22$.

86. See David Orgon Coolidge, Same-Sex Marriage? Baehr v. Miike and the Meaning of Marriage, 38 S. Tex. L. REV. 1, 15-16 (1997).

87. The Hawaii Constitution, article 1, section 23, provides that "[t]he legislature shall have the power to reserve marriage to opposite-sex couples."

88. HaW. Rev. Stat. AnN. § 572-1 (LexisNexis 2009). The legislature recognized only reciprocal beneficiary status for same-sex couples. Id. § 572C-4. 
independently of the Federal Constitution. Consequently, the court was free to depart from the Minnesota Supreme Court's ruling in Baker v. Nelson that the inability of same-sex couples to procreate justified their exclusion from the institution of marriage under the Federal Equal Protection Clause. The questions before the court under the State's equal protection clause were whether marriage is a "civil right" and, if so, whether same-sex couples could justifiably be excluded from the institution of marriage as so defined.

In concluding that marriage is a "civil right," the Hawaii Supreme Court relied on the due process section of Loving, in which the United States Supreme Court characterized marriage as a "basic civil right" that is "essential to the orderly pursuit of happiness." ${ }^{89}$ This is the moment when the court recognized a hint of synergy between liberty and equality in Baehr. Once the court had linked marriage to the pursuit of happiness (rather than to procreation), it was in a position to reject the defendant's argument that same-sex couples are not similarly situated to opposite-sex couples for purposes of marriage because of their inability to procreate. That ruling then set the stage for the court to become the first state high court to announce that the classification in an opposite-sex marriage statute is a sex-based, suspect classification that is not vulnerable to the equal application defense and that must be subjected to strict scrutiny. Needless to say, if the State's equal protection clause had not explicitly protected "civil rights," and if the court had not recognized the synergy between liberty and equality in construing the phrase "civil rights," the case might have come out very differently, given that the court was so severely splintered.

\section{BAKER V. STATE: EquAL BENEFITS Without EquAL STATUS}

The second major marriage equality case to be brought under a state constitution was Baker v. State. ${ }^{90}$ The plaintiffs were same-sex couples who claimed that Vermont's opposite-sex marriage statute violated several provisions of the state constitution. ${ }^{91}$ The Vermont Supreme Court chose to focus exclusively on the common benefits clause, which provides: "That government is, or ought to be, instituted for the common benefit, protection, and security of the people, nation, or community; and not for the particular emolument or advantage of any single person, family, or set of persons, who are a part only of that community ...." ${ }^{2}$ The clause promotes the principle of equality, although technically it is neither an equal protection clause nor an equal rights amendment. ${ }^{93}$

\footnotetext{
89. Loving v. Virginia, 388 U.S. 1, 12 (1967).

90. Baker v. State, 744 A.2d 864 (Vt. 1999).

91. Id. at $870 \mathrm{n} .2$.

92. VT. CONST. ch. I, art. 7.

93. Baker v. State, 744 A.2d at 870-71.
} 
Early in its opinion, the Vermont Supreme Court discussed the historical origins of the common benefits clause. The clause was originally designed to prevent the establishment of the equivalent of British royalty, but the court found that the American Revolution had also "tapped deepseated domestic antagonisms" against such groups as "New Yorkers claiming Vermont lands." ${ }^{94}$ Consequently, the court concluded that the common benefits clause was not "principally concerned with civil rights for African-Americans and other minorities," but rather with "access to public benefits and protections for the community as a whole." 95

Given the historical origins of the common benefits clause, the Vermont Supreme Court announced that, when analyzing laws challenged under the clause, it would apply a relatively uniform standard of non-deferential, lowlevel scrutiny (rather than the multi-tiered analysis developed under the Fourteenth Amendment). ${ }^{96}$ It described its test for low-level scrutiny under the common benefits clause as "broadly deferential to the legislative prerogative to define and advance governmental ends, while vigorously ensuring that the means chosen bear a just and reasonable relation to the governmental objective." 97 The court also explained that it would consider three factors when applying its test for low-level scrutiny: “(1) the significance of the benefits ... of the challenged law; (2) whether the omission of members of the community from the benefits... of the challenged law promotes the government's stated goals; and (3) whether the classification is significantly underinclusive or overinclusive."98

In considering the first factor, the Vermont Supreme Court examined the significance of civil marriage under the common benefits clause. ${ }^{99}$ The court followed in the footsteps of Baehr v. Lewin ${ }^{100}$ by noting that, in the due process section of Loving $v$. Virginia, ${ }^{101}$ the United States Supreme Court observed that "“[t]he freedom to marry has long been recognized as one of the vital personal rights." ${ }^{102}$ The court therefore concluded that the multitude of benefits and obligations that flow from civil marriage "significantly enhance the quality of life in our society." 103

This is the moment when one can begin to see a hint of synergy

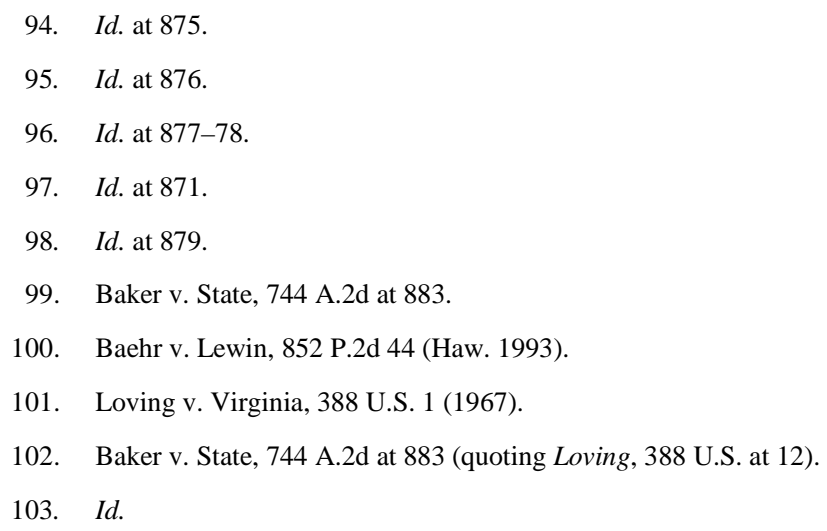


between liberty and equality in Baker v. State. The court had defined the "common benefit" of marriage by reference to the definition of the fundamental right to marry in Loving. Therefore, the court was prepared to focus throughout the remainder of its opinion on the link between marriage and the pursuit of happiness, rather than on the link between marriage and procreation.

Having established the significance of the benefits at issue under the common benefits clause, the court next considered the nature of the classification that excluded the plaintiffs from access to those benefits. The majority announced in a single sentence that the marriage statute excluded "anyone who wishe[d] to marry someone of the same sex." 104 The concurring judge explained in greater detail that, although the marriage statute did "not facially discriminate on the basis of sexual orientation," there could be "no doubt" that the statute had "the effect of discriminating against lesbian and gay couples... who [were] unable to marry the life partners of their choice.” ${ }^{105}$ Because the court had chosen to focus on the link between marriage and the pursuit of happiness, it was the first state high court to understand that the classification at issue was in effect a sexual orientation-based classification. ${ }^{106}$

The Vermont Supreme Court was aware of the fact that the Hawaii Supreme Court had found a facial sex-based classification in Baehr, but the court disagreed with the Hawaii Supreme Court's analysis. The court thought that the Vermont marriage statute was "facially neutral" with regard to gender because it did not "single out men or women as a class for disparate treatment." ${ }^{107}$ Rather, it prohibited both "men and women equally from marrying a person of the same sex." ${ }^{108}$ In other words, the court permitted the State to assert the equal application defense in response to the plaintiffs' claim that the statute contained a sex-based classification. ${ }^{109}$ The court distinguished Loving on the ground that, in Loving, the United States Supreme Court had found evidence that the legislature's "real purpose was to maintain the pernicious doctrine of white supremacy." "The court could find no evidence of a comparably pernicious legislative motive to maintain male supremacy. ${ }^{111}$ In rejecting the plaintiffs' argument that the evidence demonstrated a discriminatory purpose, the court said:

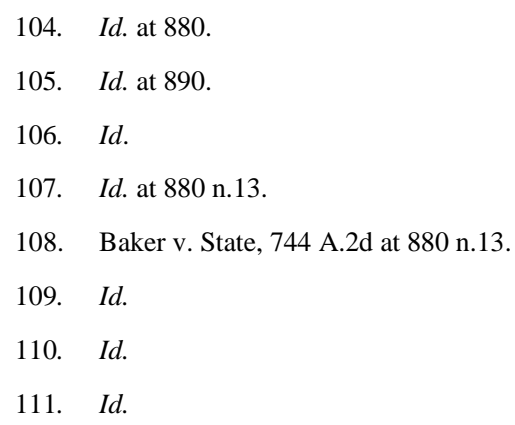


It is one thing to show that long-repealed marriage statutes subordinated women to men within the marital relation. It is quite another to demonstrate that the authors of the marriage laws excluded same-sex couples because of incorrect and discriminatory assumptions about gender roles or anxiety about gender-role confusion. ${ }^{112}$

The court concluded that, in the absence of the latter type of evidence, the plaintiffs had failed to prove that the statute contained a sex-based classification. ${ }^{113}$

One judge, Judge Johnson, dissented in part with regard to the classification issue. ${ }^{114}$ She emphasized the fact that the statute did not classify facially on the basis of sexual orientation, and she stated her opinion that "this is a straightforward case of sex discrimination." 115 Furthermore, she took the position that the sex-based classification ought to trigger heightened scrutiny under the common benefits clause. ${ }^{116}$ She found that the equal application defense did not apply because marriage is an individual right, not a group right. ${ }^{117}$ She also expressed her opinion that the sex-based classification in the Vermont marriage statute was a "vestige of sex-role stereotyping." "118 She acknowledged that the sex-role stereotyping at issue harmed both men and women, ${ }^{119}$ but she thought that the common benefits clause precluded the State from continuing to give "credence to generally discredited sex-role stereotyping." "120

Once the Vermont Supreme Court had determined that the classification at issue was in effect a sexual-orientation based classification, its third task was to consider whether the classification was justifiable under its test of non-deferential, low-level scrutiny. More specifically, the court had to determine whether the State could prove a "legitimate public purpose" ${ }^{121}$ for the sexual orientation-based classification and, if so, whether the State could show that the means "reasonably relate[d]" to that end. ${ }^{122}$ It should be noted that the Vermont Supreme Court was the first state high court to consider the

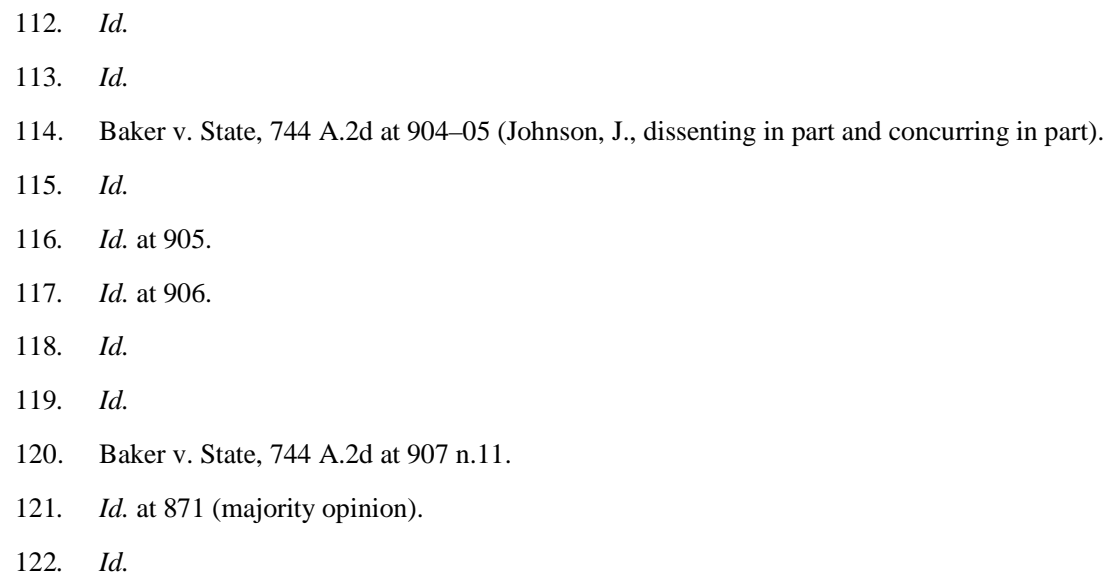


question of whether the state had established an adequate justification for a denial of marriage equality under a state constitution. Perhaps that is what motivated the State to advance such a dizzying array of justifications for its opposite-sex marriage statute. ${ }^{123}$ The court seriously considered only two of them. ${ }^{124}$

First, the Vermont Supreme Court focused on the State's argument that the statutory exclusion of same-sex couples from marriage promotes procreation and furthers "the link between procreation and child rearing," which serves to ensure that the offspring of opposite-sex couples "are considered legitimate and receive ongoing parental support." ${ }^{25}$ The court acknowledged that these are valid public interests and that the overwhelming majority of births in Vermont result from natural conception. ${ }^{126}$ However, it also noted that many opposite-sex couples marry for reasons unrelated to procreation. ${ }^{127}$ Moreover, married opposite-sex couples who are incapable of having children through natural conception may either adopt children or utilize assisted-reproductive techniques. ${ }^{128}$ Therefore, the court found that "if the purpose of the statutory exclusion of same-sex couples is to 'further[] the link between procreation and child rearing,' then it is significantly underinclusive." ${ }^{129}$ Furthermore, the court found that the exclusion of samesex couples with children from the institution of marriage "exposes their children to the precise risks that the State argues the marriage laws are designed to secure against," thereby making the statutory exclusion of all same-sex couples significantly over-inclusive. ${ }^{130}$ In other words, the court said, the statutory exclusion of all same-sex couples "treats persons who are similarly situated for purposes of the law, differently," and for this reason the court found that the means were not reasonably related to the end. ${ }^{131}$

Second, the State argued that, "because same-sex couples cannot conceive a child on their own, their exclusion [from marriage] promotes a 'perception of the link between procreation and child rearing,' and that to discard [the perception] would 'advance the notion that mothers and fathers ... are mere surplusage to the functions of procreation and child rearing." " 132 The court found that, even if sending a public message about

\footnotetext{
123. Id. at 881, 884-85.

124. Id. at 881.

125. Id.

126. Baker v. State, 744 A.2d at 881.

127. Id.

128. Id.

129. Id.

130. Id. at 882.

131. Id.

132. Baker v. State, 744 A.2d at 882.
} 
the link between procreation and child-rearing is a legitimate governmental objective, nevertheless the exclusion of same-sex couples from marriage is a grossly under-inclusive means to that end. ${ }^{133}$ The court noted that most of the people who use assisted-reproductive techniques are "infertile married couples." 134 The court further noted that the State had never suggested that a married couple's use of assisted-reproductive techniques would undermine anyone's sense of parental responsibility. ${ }^{135}$ Nor had the State taken any steps to restrict access to such techniques as a matter of public policy. ${ }^{136}$ Consequently, there was no reasonable basis to conclude that a same-sex couple's use of assisted-reproductive technologies would undermine society's perception of the link between procreation and child-rearing. ${ }^{137}$

Having determined that the plaintiffs had been unconstitutionally denied the benefits of marriage in violation of the common benefits clause, the Vermont Supreme Court turned to the question of what would be an appropriate remedy. The plaintiffs had sought declaratory relief and an injunction prohibiting the State from denying marriage licenses to same-sex couples. ${ }^{138}$ The court observed, however, that the plaintiffs' claims and their arguments on appeal had focused primarily on the consequences of being excluded from "the statutory benefits, protections, and security incident to marriage under Vermont law." ${ }^{339}$ Therefore, the court decided to hold "only" that the plaintiffs were entitled to obtain "the [statutory] benefits and protections afforded by Vermont law to married opposite-sex couples." 140 The court then left it up to the legislature to craft "an appropriate means of addressing this constitutional mandate." 141 The court suggested that the legislature could extend marriage to same-sex couples, but it also indicated that the legislature could create an alternative status for same-sex couples, such as domestic partnerships. ${ }^{142}$ The court retained jurisdiction over the case, stating: "In the event that the benefits and protections in question are not statutorily granted, plaintiffs may petition this Court to order the remedy

\footnotetext{
133. Id. at 882-83.

134. Id. at 882.

135. Id.

136. Id.

137. Id.

138. Baker v. State, 744 A.2d at 886.

139. Id.

140. Id.

141. Id.

142. Id. at 886-87. The court fully understood that such an "alternative status" might itself be the subject of a future constitutional challenge: "While some future case may attempt to establish that —notwithstanding equal benefits and protections under Vermont law—-the denial of a marriage license operates per se to deny constitutionally-protected rights, that is not the claim we address today." Id. at 886.
} 
they originally sought." 143

Judge Johnson, dissenting in part, objected to the majority's "novel and truncated remedy." 144 She took the position that it is "not only the prerogative but the duty of courts to provide prompt relief for violations of individual civil rights." ${ }^{145}$ She stated her opinion that this principle ensures that "laws enacted through the will of the majority do not unconstitutionally infringe upon the rights of a disfavored minority." ${ }^{146}$ Since the majority had found that the plaintiffs were entitled to those benefits and protections afforded under Vermont law to married opposite-sex couples, she suggested that "the most straightforward and effective remedy" would be to issue an injunction prohibiting the State from denying the plaintiffs' applications for marriage licenses solely because they were couples of the same sex. ${ }^{147}$ After all, that was the remedy which the trial court judge had awarded to the plaintiffs in Baehr. ${ }^{148}$

Judge Johnson somewhat disparagingly described the majority's remedy as "little more than a declaration of rights." ${ }^{149}$ Furthermore, because the majority had suspended its declaratory judgment, she ultimately characterized the majority's remedy as an "advisory opinion that leaves plaintiffs without redress and sends the matter to an uncertain fate in the Legislature." ${ }^{150}$ She must have experienced mixed emotions a few months later when the Vermont legislature took action in a timely fashion but chose to create civil unions for same-sex couples, rather than granting them equal access to civil marriage. ${ }^{151}$

The Vermont Supreme Court was the first state high court to characterize the classification in an opposite-sex marriage statute as an implicit sexual orientation-based classification. The court based its description of the classification at issue upon its understanding that the "common benefit" of marriage is "one of the vital personal rights" 152 essential to the orderly pursuit of happiness. The court thus understood that the opposite-sex marriage statute would have the effect of preventing all lesbian and gay same-sex couples from marrying the life partners of their

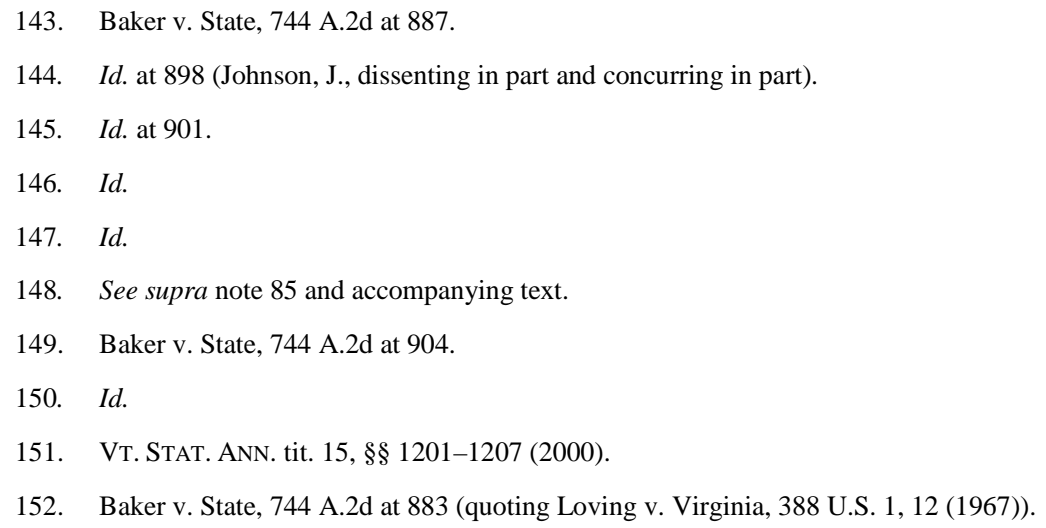


choice. Unlike the Hawaii Supreme Court, ${ }^{153}$ the Vermont Supreme Court did not focus on the language of gender that appeared on the face of the opposite-sex marriage statute. By describing the classification at issue as an implicit sexual orientation-based classification, the Vermont Supreme Court might have enhanced the public's understanding of the basis for the plaintiffs' claim to marriage equality, and without a doubt the court made it possible to ignore the intricacies of the equal application defense.

By characterizing the classification at issue as a sexual orientationbased classification, the Vermont Supreme Court also opened the door to the application of non-deferential, low-level scrutiny. As a result, the court became the first state high court to scrutinize the state's justifications for its opposite-sex marriage statute (e.g., procreation and furthering the link between procreation and child-rearing) and to hold that the state had failed to carry its burden of justification because the means were not reasonably related to the ends. Nevertheless, the court found only a violation of the common benefits clause. Therefore, the court concluded that the plaintiffs needed no more by way of a remedy than a declaration that they were entitled to the same statutory benefits and protections as those that Vermont law afforded married opposite-sex couples. That holding set the stage for the Vermont legislature to create the unique institution of civil unions for samesex couples.

Baker v. State represents a very significant step forward in the evolution of marriage equality for same-sex couples. At the same time, it is a case in which the court chose to focus exclusively on the common benefits clause challenge, which was in essence an equality claim. Consequently, the court was in a position to be able to hold that the plaintiffs were entitled to no more than the statutory benefits incident to marriage, and not to the full status of marriage.

\section{GOODRIDGE V. DEPARTMENT OF PUBLIC HEALTH: EQUAL BENEFITS AND EQUAL STATUS}

The plaintiffs in Goodridge v. Department of Public Health ${ }^{154}$ were same-sex couples who had learned the lessons of Baker v. State. ${ }^{155}$ Their complaint asserted both a liberty claim and an equality claim under the state constitution of Massachusetts, ${ }^{156}$ and their complaint sought a declaratory judgment that "the exclusion of the [p]laintiff couples and other qualified same-sex couples from access to marriage licenses, and the legal and social status of civil marriage, as well as the protections, benefits and obligations

\footnotetext{
153. See generally Baehr v. Lewin, 852 P.2d 44 (Haw. 1993).

154. Goodridge v. Dep’t of Pub. Health, 798 N.E.2d 941 (Mass. 2003).

155. Baker v. State, 744 A.2d 864.

156. Goodridge, 798 N.E.2d at 950.
} 
of marriage, violates Massachusetts law." ${ }^{157}$ Specifically, the plaintiffs alleged that the State's marriage law violated article I of the State's constitution, which provides in relevant part:

All people are born free and equal and have certain natural, essential and inalienable rights; among which may be reckoned the right of enjoying and defending their lives and liberties; . . . in fine, that of seeking and obtaining their safety and happiness. Equality under the law shall not be denied or abridged because of sex, race, color, creed or national origin. ${ }^{158}$

The word "sex" had been added to article I in 1976, when the people of Massachusetts had voted in favor of that State's equal rights amendment. ${ }^{159}$ The relevant legislative history suggested that the equal rights amendment would have "no effect upon the allowance or denial of homosexual marriages." 160 Rather, it indicated that the amendment would address only those laws that treated persons of opposite sexes differently. ${ }^{161}$

The first question before the Supreme Judicial Court of Massachusetts was one of statutory interpretation. The legislation at issue set minimum qualifications for obtaining "a marriage license." 162 The issue was whether the term "marriage" could be construed as permitting same-sex couples to marry. The court held that the "everyday meaning" of "marriage" is the "legal union of a man and woman as husband and wife." 163 Therefore, the court held that the undefined word "marriage" in the State's marriage license statute could not be construed to permit same-sex couples to marry. ${ }^{164}$

The larger question before the Supreme Judicial Court of Massachusetts was whether the opposite-sex marriage statute violated the state constitution. Although the court had construed the statute so as to honor the traditional definition of marriage, the plurality emphasized that "history cannot and does not foreclose the constitutional question." 165 The court observed that the constitutional issue might be analyzed in two ways: 1) Did the marriage statute deny the constitution's guarantee of equality? 2) Did the

\footnotetext{
157. Id.
}

158. MASs. CONST. pt. 1, art. I (amended 1976) (as amended by article 106 of the amendments to the constitution of the commonwealth, which is referred to as the equal rights amendment).

159. Goodridge, 798 N.E.2d at 992 (Cordy, J., dissenting). The equal rights amendment had first been approved by two constitutional conventions of the legislature. Id.

160. Id. at 993.

161. Id.

162. The text of the challenged marriage statute is summarized in the plurality opinion. Id. at 951-52 (plurality opinion).

163. Id. at 952 (quoting BLACK’s LAW DictionARY 986 (7th ed. 1999)).

164. Goodridge, 798 N.E.2d at 953.

165. Id. 
constitutional guarantee of liberty secure to each of the plaintiffs the right to marry his or her "chosen partner"? ${ }^{166}$ The three-judge plurality considered both questions simultaneously, while the concurring judge collapsed them into a single question by asking whether the marriage statute contained a classification that burdened a fundamental right in violation of the state constitution's guarantee of equality. ${ }^{167}$ The court pointed out that, in matters involving family law (such as interracial marriage), "the two constitutional concepts frequently overlap, as they do here," 168 thereby suggesting that the court understood the synergistic potential of considering liberty and equality simultaneously. The court also observed: "The Massachusetts Constitution is, if anything, more protective of individual liberty and equality than the Federal Constitution; it may demand broader protection for fundamental rights; and it is less tolerant of government intrusion into the protected spheres of private life." 169

In a single passage, the court described civil marriage, identified the issue in the case, and announced its holding:

Marriage is a vital social institution. The exclusive commitment of two individuals to each other nurtures love and mutual support; it brings stability to our society. For those who choose to marry, and for their children, marriage provides an abundance of legal, financial, and social benefits. In return it imposes weighty legal, financial, and social obligations. The question before us is whether, consistent with the Massachusetts Constitution, the Commonwealth may deny the protections, benefits, and obligations conferred by civil marriage to two individuals of the same sex who wish to marry. We conclude that it may not. The Massachusetts Constitution affirms the dignity and equality of all individuals. It forbids the creation of second-class citizens. ...

-...

Barred access to the protections, benefits, and obligations of civil marriage, a person who enters into an intimate, exclusive union with another of the same sex is arbitrarily deprived of membership in one of our community's most rewarding and cherished institutions. That exclusion is incompatible with the constitutional principles of respect for individual autonomy and equality under law. ${ }^{170}$

\footnotetext{
166. Id.

167. Id. at 970 (Greaney, J., concurring).

168. Id. at 953 (plurality opinion).

169. Id. at $948-49$.

170. Goodridge, 798 N.E.2d at 948-49.
} 
Three judges dissented from the court's bold holding. They would have found that marriage is a union between one man and one woman. ${ }^{171}$ Then they would have ruled that the marriage statute imposed "no restriction on the right of any plaintiff to enter into marriage" because "[e]ach is free to marry a willing person of the opposite sex." ${ }^{\text {"172 }}$

The court's definition of marriage (i.e., the exclusive commitment of two individuals to each other) reflects its understanding that the right to marry is a civil right, and that marriage is linked to the pursuit of happiness, rather than to procreation. The court's statement of the issue is implicitly premised on the view that same-sex couples and opposite-sex couples are similarly situated with regard to the institution of marriage (as defined by the court). And the court's unprecedented holding extends to same-sex couples both the status and the benefits of marriage. By honoring the dignity and equality of all individuals and by forbidding the creation of second-class citizens, the court's holding dramatically demonstrates the synergistic power of liberty and equality when they are analyzed as overlapping constitutional claims.

By considering liberty and equality simultaneously, the court broke away from cases such as Baker v. Nelson ${ }^{173}$ and Baehr v. Lewin ${ }^{174}$ that had rejected the liberty claim outright because same-sex couples do not fit the traditional definition of marriage as the union of one man and one woman. And, by discussing equality and liberty simultaneously, the court broke away from cases such as Baker $v$. Nelson that had rejected the equality claim outright because same-sex couples are not similarly situated to opposite-sex couples with regard to the ability to procreate. Finally, by considering liberty and equality simultaneously, the court parted company with cases such as Baker v. State that had extended to same-sex couples only the benefits of marriage, and not the status of marriage.

Even though the court initially discussed liberty and equality simultaneously, the court still had to consider liberty and equality separately in order to determine what level of scrutiny to apply. With regard to the due process claim, the court splintered. The concurring judge found that "the right to marry" (including the right to marry someone of the same sex) is a "fundamental right" subject to strict scrutiny under the equal protection clause. ${ }^{175}$ Therefore, if he had considered the due process claim, he would have applied strict scrutiny. The three dissenting judges found that the "right

171. Id. at 975 n.3 (Spina, J., dissenting) (citing Milford v. Worcester, 7 Mass. (1 Tyng) 48 (1810)).

172. Id. at 975.

173. Baker v. Nelson, 191 N.W.2d 185 (Minn. 1971).

174. Baehr v. Lewin, 852 P.2d 44 (Haw. 1993).

175. Goodridge, 798 N.E.2d at 970, 972-73 (Greaney, J., concurring). 
to same-sex marriage" is not a fundamental right, ${ }^{176}$ and therefore, at best, they would have applied deferential low-level scrutiny. ${ }^{177}$

The three-judge plurality described the right to marry as the "right to marry the person of one's choice," 178 and it also said that marriage has long been termed a "civil right." ${ }^{179}$ But then the plurality announced that it would subject the statute to low-level scrutiny, ${ }^{180}$ although it would be a form of low-level scrutiny that "is not 'toothless.", 181 The plurality offered the following explanation for its decision not to apply heightened scrutiny: "Because the statute does not survive rational basis review, we do not consider the plaintiffs' arguments that this case merits strict judicial scrutiny." 182

Turning to the equal protection claim, all of the members of the court agreed that the statute did not contain a facial sexual orientation-based classification. ${ }^{183}$ But then the court once again splintered. The concurring judge, who rejected the equal application defense, found that the statute contained a facial sex-based classification. ${ }^{184} \mathrm{He}$ would have been willing to apply strict scrutiny under the equal rights amendment, but he had to acknowledge that the voters who had approved the equal rights amendment in 1976 did not intend for it to have the effect of allowing or denying samesex marriage. ${ }^{185}$ Therefore, in the end, he took the position that the classification at issue ought to be subjected to strict scrutiny because it burdened a fundamental right. ${ }^{186}$

The three dissenting judges found that the classification was not a sexbased classification since the statute applied to men and women "in precisely the same way." "187 Rather, they took the position that the statute distinguished facially between opposite-sex couples (who could obtain a marriage license) and same-sex couples (who could not). ${ }^{188}$ Because the dissenting judges characterized this classification as non-suspect, they would

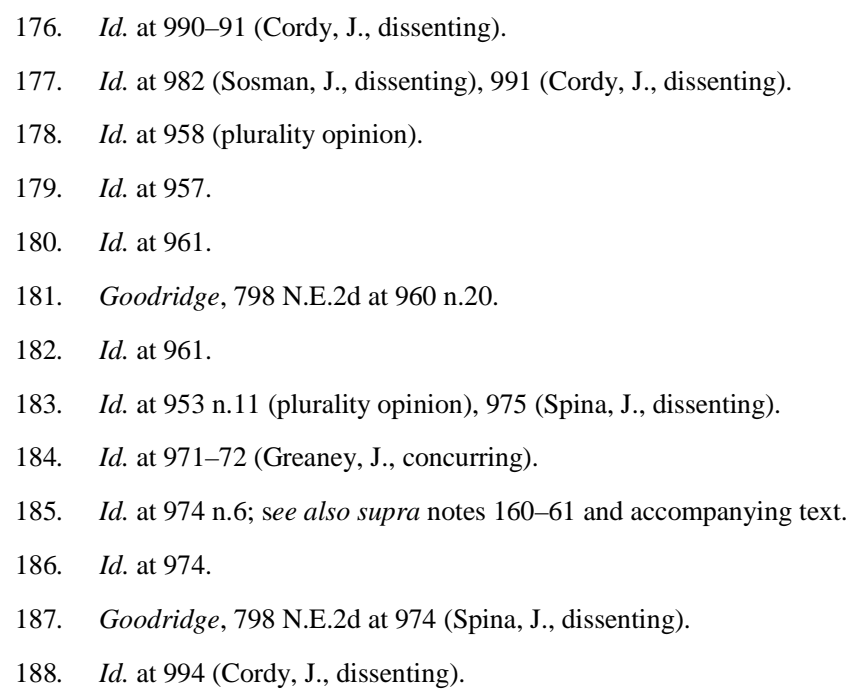


have applied deferential low-level scrutiny. ${ }^{189}$

The plurality did not consider the question of whether the statute contained a sex-based classification. Instead, it agreed with the dissenting judges that the statute facially distinguished between same-sex couples and opposite-sex couples. ${ }^{190}$ At this point in its analysis, however, the plurality parted company with the dissenters. The plurality suggested that the distinction between same-sex couples and opposite-sex couples in effect classified on the basis of sexual orientation because it deprived an individual of access to the institution of marriage when his or her chosen partner was a person of the same sex. ${ }^{191}$ The plurality then announced that it would once again apply the type of low-level scrutiny that "is not 'toothless.", ${ }^{192}$ It offered the following explanation for its failure to consider whether "sexual orientation" is a "suspect" classification: "We have not previously considered whether 'sexual orientation' is a 'suspect' classification. Our resolution of this case does not require that inquiry here.” 193

Since the plurality thought that both the liberty claim and the equality claim ought to be subjected to the type of low-level scrutiny that "is not 'toothless,"' the plurality put the burden on the defendant to prove that the classification in the statute bore a "reasonable relationship" to a legitimate objective. ${ }^{194}$ This resembled the level of scrutiny that the Vermont Supreme Court had applied in Baker v. State. The defendant in Goodridge set forth three justifications, ${ }^{195}$ but a majority of the court rejected them all.

The first of the justifications was "providing a 'favorable setting for procreation."”196 The trial court judge had endorsed this justification when granting the defendant's motion for a summary judgment. The trial court judge had ruled that "the state's interest in regulating marriage is based on the traditional concept that marriage's primary purpose is procreation.”197 The plurality said: "This is incorrect." 198

The plurality opinion went on to explain that the State's civil marriage laws "do not privilege procreative heterosexual intercourse between married people above every other form of adult intimacy and every other means of

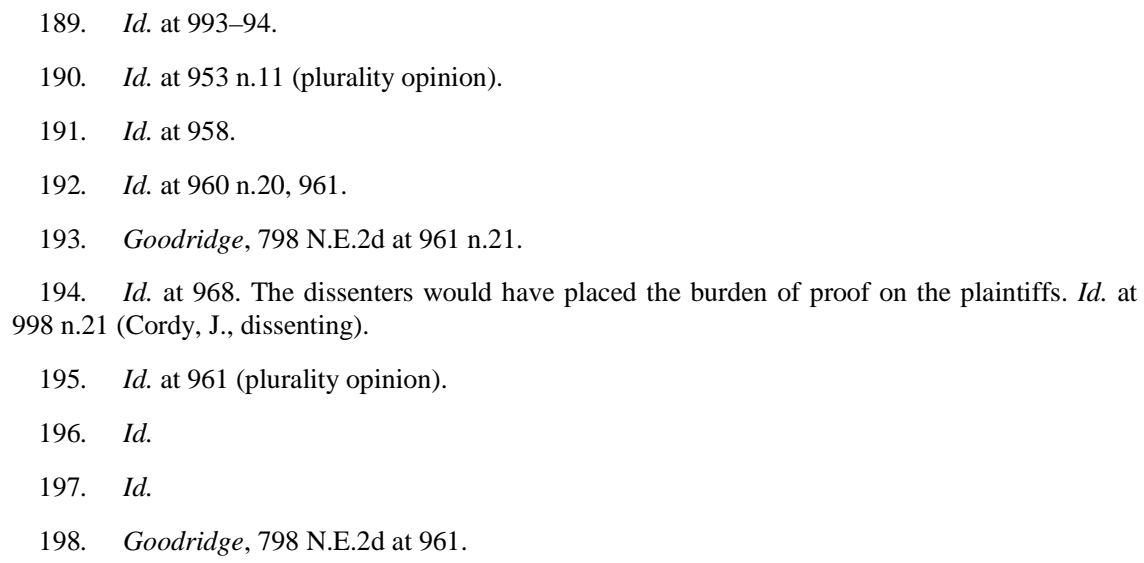


creating a family." ${ }^{199}$ Moreover, the plurality emphatically asserted that "it is the exclusive and permanent commitment of the marriage partners to one another, not the begetting of children, that is the sine qua non of civil marriage." 200 The plurality opinion observed that " $[t]$ he 'marriage is procreation' argument singles out the one unbridgeable difference between same-sex and opposite-sex couples, and transforms that difference into the essence of legal marriage." ${ }^{201}$ In so doing, the plurality thought that "the State's action confer[red] an official stamp of approval on the destructive stereotype that same-sex relationships are inherently unstable and inferior to opposite-sex relationships and are not worthy of respect."202

The second of the justifications was "ensuring the optimal setting for child rearing." 203 The plurality noted that the State's first justification "shades imperceptibly into its second." ${ }^{204}$ The plurality acknowledged that "[p]rotecting the welfare of children" is undoubtedly a legitimate objective. ${ }^{205}$ However, it took the position that restricting marriage to opposite-sex couples could not possibly further that objective, since samesex couples also raise children. ${ }^{206}$

Moreover, the State had not offered evidence to prove that forbidding marriage to same-sex couples would increase the number of opposite-sex couples who would want to marry and have children. ${ }^{207}$ Therefore, there was no "reasonable relationship" between the State's marriage statute and its "proffered goal" of protecting the "optimal setting for child rearing." 208 Instead, the State's marriage statute actually had the counterproductive effect of depriving the children of same-sex couples of the optimal setting for child-rearing. ${ }^{209}$ And the plurality could not comprehend how it could be considered rational "to penalize children by depriving them of State benefits because the State disapproves of their parents' sexual orientation." 210

The third of the justifications was "preserving scarce State and private

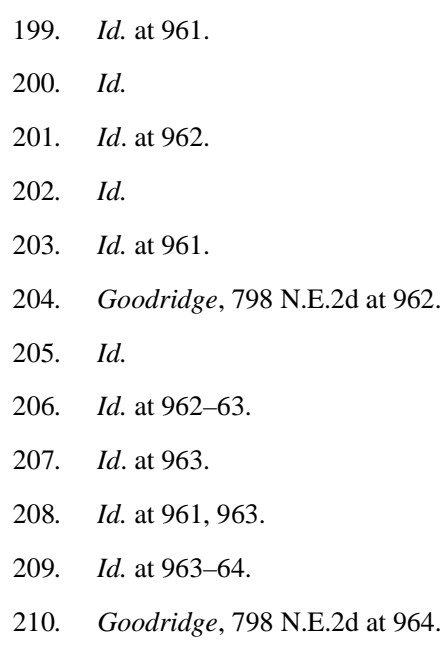


financial resources." 211 Because the plurality was applying low-level scrutiny, it could not reject this asserted legitimate objective outright. Instead, it had to ask whether the means bore a reasonable relation to the end. The plurality noted that the State assumed that same-sex couples are more financially independent than opposite-sex couples, and therefore they are less in need of public marital benefits (such as tax advantages) or private marital benefits (such as employer-financed health insurance). ${ }^{212}$ But the plurality found that the State's assumption was flawed because "many samesex couples, such as many of the plaintiffs in this case, have children and other dependents (here, aged parents) in their care."213 Furthermore, the plurality observed that the State does not require opposite-sex couples to demonstrate their financial dependence in order to receive either public or private marital benefits. ${ }^{214}$ Rather, the State makes those benefits available to opposite-sex married couples "regardless of whether they mingle their finances or actually depend on each other for support."215

After rejecting all three of the State's justifications for the opposite-sex marriage statute, the court turned its attention to a final rationale that had been developed by several amici. They had asserted that "broadening civil marriage to include same-sex couples will trivialize or destroy the institution of marriage as it has historically been fashioned." 216 The plurality acknowledged that its decision did significantly change the traditional definition of marriage, but it insisted that its decision would "not disturb the fundamental value of marriage in our society." 217 After all, "the plaintiffs [sought] only to be married, not to undermine the institution of civil marriage." 218 The plurality emphasized this point by drawing the following analogy:

Recognizing the right of an individual to marry a person of the same sex will not diminish the validity or dignity of opposite-sex marriage, any more than recognizing the right of an individual to marry a person of a different race devalues the marriage of a person who marries someone of her own race. ${ }^{219}$

If anything, the plurality observed, "extending civil marriage to same-sex

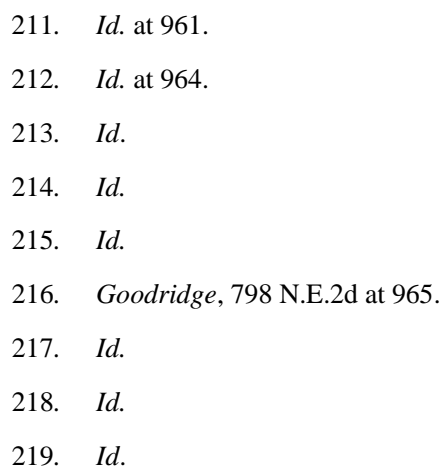


couples reinforces the importance of marriage to individuals and communities" because the fact that same-sex couples are "willing to embrace marriage's solemn obligations of exclusivity, mutual support, and commitment to one another is a testament to the enduring place of marriage in our laws and in the human spirit.”220

The plurality's discussion of the State's justifications for the sexual orientation-based classification in the marriage statute in Goodridge was so extensive because the Supreme Judicial Court of Massachusetts examined the justifications stereoscopically through the lenses of both liberty and equality. By contrast, in Baker v. State, the Vermont Supreme Court examined the State's justifications solely through the lens of the common benefits clause. ${ }^{221}$ As a result, the Vermont Supreme Court focused almost exclusively on the question of whether the statutory classification was either under-inclusive or over-inclusive. ${ }^{222}$ The plurality opinion in Goodridge paid attention to that issue, but it went beyond a consideration of that question as well.

For example, the courts in both Baker v. State and Goodridge recognized that, if the state asserts that the justifications for an opposite-sex marriage statute are promoting procreation and protecting the welfare of children, then the legislative classification at issue is both under-inclusive and over-inclusive because it does not exclude opposite-sex couples who are unable to procreate naturally or who want to marry for reasons unrelated to procreation, and it does not include same-sex couples with children. But the plurality in Goodridge went beyond that line of analysis and focused on reframing the definition of civil marriage as well. It took the position that it is the "exclusive and permanent commitment of the marriage partners to one another, not the begetting of children, that is the sine qua non of civil marriage."223 It then explained that, when the State defines and justifies marriage by reference to procreation, it is stigmatizing same-sex relationships by suggesting that they are inherently unstable. Thus, by looking at marriage through the lenses of both liberty and equality simultaneously, the plurality was able to reframe the definition of marriage so as to broaden the institution of civil marriage without destroying it.

Having found that the State's marriage statute failed to survive nondeferential, low-level scrutiny, the plurality opinion in Goodridge considered the appropriate form of relief. It noted that, when a plaintiff makes an equal protection challenge, a court has two options: 1) strike the statute down; or 2) extend it to the plaintiffs. ${ }^{224}$ A majority of the court in

\footnotetext{
220. Id.

221. Baker v. State, 744 A.2d 864 (Vt. 1999).

222. See supra notes $125-37$ and accompanying text.

223. Goodridge, 798 N.E.2d at 961.

224. Id. at 969.
} 
Goodridge opted to extend the marriage statute to the plaintiffs. ${ }^{225}$

The plurality announced that it would construe civil marriage to mean "the voluntary union of two persons as spouses, to the exclusion of all others." $^{226}$ It reasoned that reformulating the definition of marriage redressed the plaintiffs' constitutional injury while advancing the State's legitimate interests. ${ }^{227}$ The plurality noted that the plaintiffs had asked for a declaratory judgment that the State's marriage license statute violated Massachusetts law, but they had not asked for an injunction ordering the State to issue marriage licenses to the plaintiffs. ${ }^{228}$ Therefore, it declared that "barring an individual from the protections, benefits, and obligations of civil marriage solely because that person would marry a person of the same sex violates the Massachusetts Constitution." ${ }^{229}$ A majority of the court vacated the summary judgment for the defendant and remanded the case to the trial court for entry of judgment consistent with the plurality's opinion. ${ }^{230}$ The court stayed the entry of judgment for " 180 days to permit the Legislature to take such action as it may deem appropriate in light of this opinion.”231

When the legislature later requested an advisory opinion from the Supreme Judicial Court of Massachusetts as to whether the court would permit the legislature to create civil unions for same-sex couples, the answer was an emphatic "no."232 A majority of the court took the position that the proposed legislation violated both the due process clause and the equal protection clause of the state constitution. ${ }^{233}$ The two dissenting judges, who would have permitted civil unions, characterized the dispute before the court as a mere "squabble over the name to be used." ${ }^{234}$ But the majority of the court characterized the proposed law as one that segregated same-sex unions from opposite-sex unions, and it adamantly asserted that "separate is seldom,

225. Id. The concurring judge agreed with the remedy ordered by the plurality. Id. at 970 (Greaney, J., concurring).

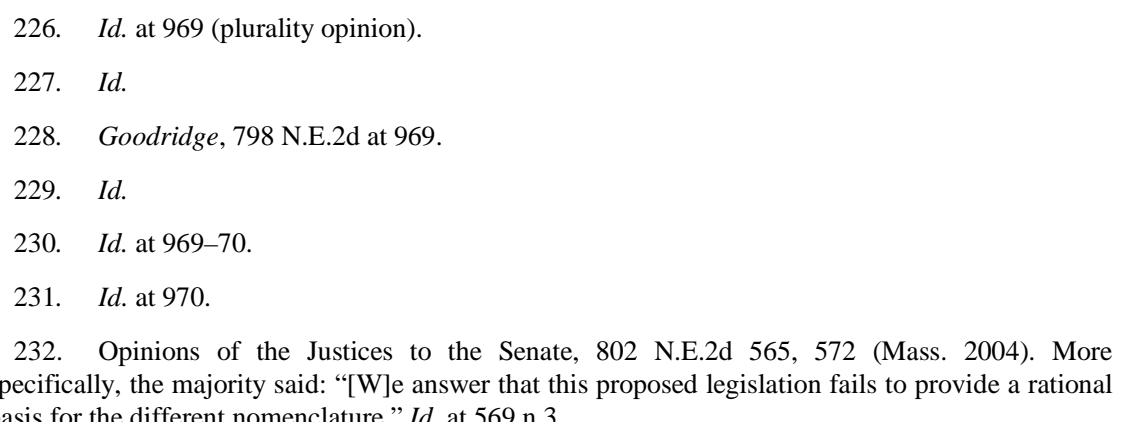
specifically, the majority said: "[W]e answer that this proposed legislation fails to provide a rational basis for the different nomenclature.” Id. at 569 n.3.

233. Id. at 572. The legislature apparently had construed the court's stay as a signal that it could create civil unions for same-sex couples, but the court explained that "[t]he [sole] purpose of the stay was to afford the legislature an opportunity to conform the existing statutes to the provisions of the Goodridge decision.” Id. at 568.

234. Id. at 572 (Sosman, J., dissenting). A third judge wrote a "separate opinion" in which he declined to consider the question posed by the legislature until after the legislature had completed its deliberative process. Id. at 580-81 (Cordy, J., dissenting). 
if ever, equal.”235 The majority of the court then explained why the proposed legislation violated both the principles of liberty and equality under the state constitution:

We recognize that the pending bill palliates some of the financial and other concrete manifestations of the discrimination at issue in Goodridge. But the question the court considered in Goodridge was not only whether it was proper to withhold tangible benefits from same-sex couples, but also whether it was constitutional to create a separate class of citizens by status discrimination, and withhold from that class the right to participate in the institution of civil marriage along with its concomitant tangible and intangible protections, benefits, rights, and responsibilities. Maintaining a second-class citizen status for samesex couples by excluding them from the institution of civil marriage is the constitutional infirmity at issue. ${ }^{236}$

Thus, the court's advisory opinion, like its original opinion in Goodridge, illustrates the synergistic power of joining claims for liberty with claims for equality in marriage cases brought by same-sex couples.

\section{HeRnandeZ V. Robles: After Two Steps Forward, One SteP BACK}

Post-Goodridge v. Department of Public Health, ${ }^{237}$ plaintiffs in state court marriage equality cases suffered a string of losses. ${ }^{238}$ If Goodridge took two steps forward for marriage equality, then these cases took one step back. This Section will feature just one of the cases, Hernandez v. Robles, ${ }^{239}$ on the theory that it is an excellent illustration of both the types of arguments that parties advanced and the types of opinions that courts handed down throughout this entire line of cases.

The plaintiffs in Hernandez were forty-four same-sex couples who hoped to persuade the New York Court of Appeals ${ }^{240}$ to follow in the footsteps of Goodridge. Therefore, they challenged New York's oppositesex marriage statute on the grounds that it denied them both liberty and equality under the state constitution. ${ }^{241}$ The court observed that it had the

235. Opinions of the Justices to the Senate, 802 N.E.2d at 569 (majority opinion).

236. Id. at 571.

237. Goodridge v. Dep’t of Pub. Health, 798 N.E.2d 941 (Mass. 2003).

238. In the order in which they were decided, the state high court cases in this string of losses were: Hernandez v. Robles, 855 N.E.2d 1 (N.Y. 2006); Andersen v. King County, 138 P.3d 963 (Wash. 2006); Lewis v. Harris, 908 A.2d 196 (N.J. 2006); and Conaway v. Deane, 932 A.2d 571 (Md. 2007).

239. Hernandez, 855 N.E.2d 1.

240. Id. at 5 .

241. Id. at 6 . 
power to construe the state constitution independently of the Federal Constitution, yet it also recognized that it usually looked first to the Federal Constitution for guidance. ${ }^{242}$ The court then noted that, in this case, it would not consider itself bound ${ }^{243}$ by the Supreme Court's ruling without an opinion in Baker v. Nelson. ${ }^{244}$

With regard to due process, the plaintiffs claimed that each one of them had a fundamental right "to select and marry the person of his or her choice." 245 The three-judge plurality acknowledged that "the right to marry is unquestionably a fundamental right," but it immediately reformulated the issue, stating that the plaintiffs actually were claiming "[t]he right to marry someone of the same sex." 246 Not surprisingly, given its narrow definition of the right at issue, the plurality then found (in accord with Baehr v. Lewin ${ }^{247}$ ) that the right to same-sex marriage is not a fundamental right because it is not deeply rooted in tradition. ${ }^{248}$

Judge Graffeo, who wrote the concurring opinion, defined the term "marriage" in its traditional sense as a union of one woman and one man. ${ }^{249}$ She thereby linked marriage to procreation (in accord with Baehr). The plaintiffs suggested that the link between procreation and marriage had become "anachronistic because of scientific advances in assisted reproduction technology." 250 Judge Graffeo was not persuaded, saying that "the fact remains that the vast majority of children are conceived naturally." ${ }^{251}$ Consequently, she found that the plaintiffs had no fundamental right to marry due to their inability to procreate. ${ }^{252}$

A majority of the Hernandez court thus completely rejected the Goodridge court's reasoning that the right to marry is the civil right to marry a person of one's choice. Instead, the court adopted the traditional definition of marriage (linking it to procreation) and indicated that it would apply very deferential low-level scrutiny to the opposite-sex marriage statute under the State's due process clause. ${ }^{253}$ Ironically, although the court did not consider

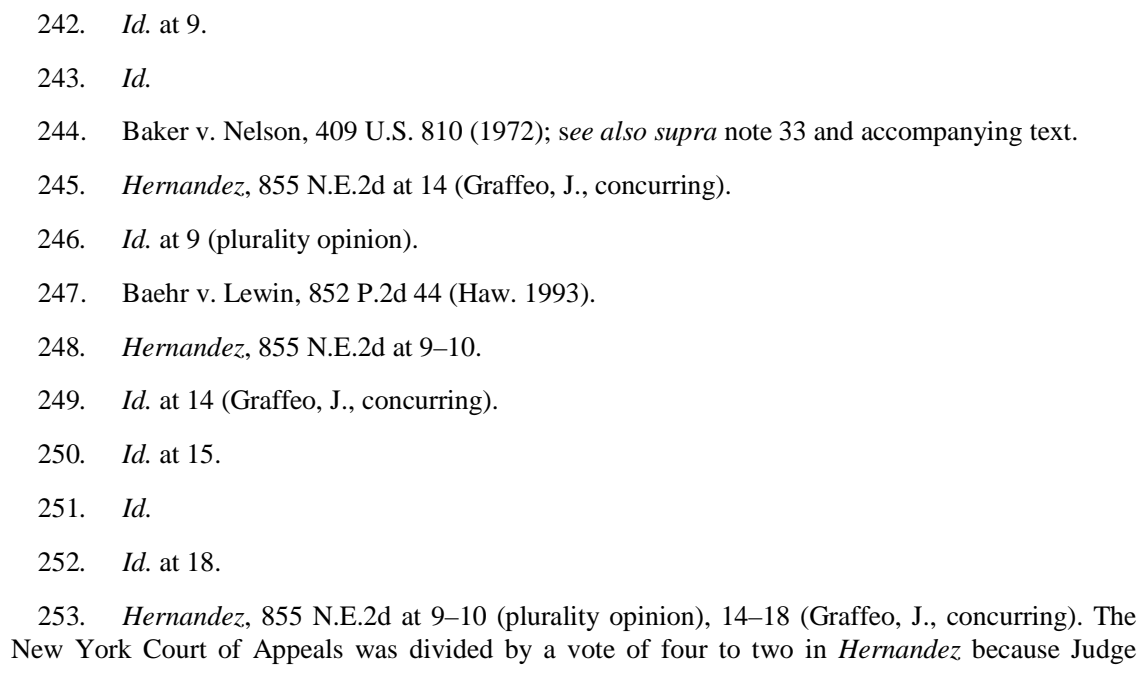


itself bound by the U.S. Supreme Court's ruling in Baker v. Nelson, nonetheless its opinion replicated the reasoning of the Minnesota Supreme Court in that early marriage equality case. ${ }^{254}$

The two dissenting judges, in an opinion authored by Chief Judge Kaye, agreed with the plaintiffs that the right to due process of law includes the fundamental right to marry, and that central to the fundamental right to marry is "the right to marry the person of one's choice." ${ }^{255}$ The dissent sharply criticized the plurality for recasting the plaintiffs' claim as one for a "new" right to same-sex marriage because it demonstrated that the plurality did not understand that the plaintiffs sought access to the historicallyrecognized institution of marriage, rather than access to a new institution. ${ }^{256}$ The dissenting judges also criticized the concurring judge for defining marriage by reference to tradition and procreation, saying that " "an argument that marriage is heterosexual because it "just is" amounts to circular reasoning.",257

Finally, the dissenters took the position that "fundamental rights, once recognized, cannot be denied to particular groups on the ground that these groups have historically been denied those rights." 258 Put another way, fundamental rights are not defined in terms of "who" is entitled to exercise them. ${ }^{259}$ Once a liberty interest has been identified as fundamental, it "must be afforded to all." ${ }^{260}$ This is the first moment when the dissenting judges in Hernandez recognized the synergy between liberty and equality. Consequently, they took the position that the marriage statute ought to be subjected to strict scrutiny because it impinged on a fundamental liberty interest. $^{261}$

With regard to equality, the plaintiffs claimed that the opposite-sex marriage statute should be subjected to heightened scrutiny because it contained either a sex-based classification or a sexual orientation-based classification. ${ }^{262}$ Both the three-judge plurality and the concurring judge took the position that the statute did not contain a sex-based classification on

Rosenblatt took no part in the case. Id. at 34.

254. See generally Baker v. Nelson, 191 N.W.2d 185 (Minn. 1971), appeal dismissed for want of a substantial federal question, 409 U.S. 810 (1972).

255. Hernandez, 855 N.E.2d at 22-23 (Kaye, C.J., dissenting).

256. Id. at 23 .

257. Id. at 26 (quoting Halpern v. Toronto, [2003] 65 O.R.3d 161, 172 (Can.)).

258. Id. at 23 .

259. Id. at 24 .

260. Id. at 24 n.1.

261. Hernandez, 855 N.E.2d at 23. Later in the dissenting opinion, Chief Judge Kaye explained that it would not be necessary to apply strict scrutiny because the state's marriage statute could not survive even rational basis review. See infra notes 280-81 and accompanying text.

262. Hernandez, 855 N.E.2d at 10 (plurality opinion). 
the theory that the statute was subject to the equal application defense. ${ }^{263}$ They parted company, however, on the question of whether the statute contained a sexual orientation-based classification. They agreed that the statute did not "facially" prohibit either heterosexuals or homosexuals from marrying, ${ }^{264}$ but they disagreed as to whether the statute in effect discriminated on the basis of sexual orientation.

The plurality found that the plaintiffs had put in sufficient circumstantial evidence of disparate treatment on the basis of sexual orientation: "Those who prefer relationships with people of the opposite sex and those who prefer relationships with people of the same sex are not treated alike, since only opposite-sex relationships may gain the status and benefits associated with marriage.”265 The concurring judge (who concurred in the result only) took the position that, at best, the statute had only a disparate impact on gays and lesbians because those homosexuals who wanted to enter into an opposite-sex marriage were not barred from obtaining marriage licenses. ${ }^{266}$ She then emphasized the fact that the plaintiffs had failed to submit any evidence of what she perceived to be the requisite proof that the legislature had crafted the marriage statute "for the purpose of disadvantaging gays and lesbians." 267

Despite the disagreement between the plurality and the concurring judge regarding the nature of the classification, they actually were in total agreement regarding the applicable level of scrutiny. The plurality took the position that, generally speaking, no more than deferential rational basis scrutiny is appropriate under the equal protection clause when plaintiffs have " "distinguishing characteristics relevant to interests the State has the authority to implement." ${ }^{268}$ In this case, the plurality found that the plaintiffs' "preference for the sort of sexual activity that cannot lead to the birth of children is relevant to the State's interest in fostering relationships that will serve children best." ${ }^{269}$ In other words, the plaintiffs as same-sex couples were not similarly situated to opposite-sex couples. And the concurring judge was of the opinion that the plaintiffs deserved no more than deferential low-level scrutiny because they had failed to prove that the legislature passed the opposite-sex marriage statute for the purpose of disadvantaging gays and lesbians. ${ }^{270}$

\footnotetext{
263. Id. at 10-11 (plurality opinion), 19-20 (Graffeo, J., concurring).

264. Id. at 20 (Graffeo, J., concurring).

265. Id. at 11 (plurality opinion).

266. Id. at 20 (Graffeo, J., concurring).

267. Id. at 20.

268. Hernandez, 855 N.E.2d at 11 (plurality opinion) (quoting Cleburne v. Cleburne Living Ctr., Inc., 473 U.S. 432, 441 (1985)).

269. Id.

270. Id. at 20 (Graffeo, J., concurring).
} 
The dissenting judges found both a sex-based classification and a sexual orientation-based classification. First, they said that the statute contained a facial, sex-based classification. They refused to recognize the equal application defense because they took the position that Loving $v$. Virginia ${ }^{271}$ “expressly rejected" that defense. ${ }^{272}$

The dissenting judges also observed that the statute, in effect, imposed different treatment on the basis of sexual orientation. From their perspective, the statute excluded gay and lesbian couples from the institution of marriage "[s]olely because of their sexual orientation ... - that is, because of who they love." ${ }^{273}$ The dissenters rejected the concurring judge's theory that the statute had only a "disparate impact" on gays and lesbians. In the words of Chief Judge Kaye: "The purported 'right' of gays and lesbians to enter into marriages with different-sex partners to whom they have no innate attraction cannot possibly cure the constitutional violation actually at issue here.”274

This is the second moment when the dissenters in Hernandez recognized the synergy between liberty and equality. Citing to Perez $v$. Sharp, ${ }^{275}$ they took the position that the right to marry is " the right of individuals, not of groups." ${ }^{276}$ Consequently, they concluded: "Limiting marriage to opposite-sex couples undeniably restricts gays and lesbians from marrying their chosen same-sex partners whom 'to [them] may be irreplaceable' - and thus constitutes discrimination based on sexual orientation." 277 Because the dissenters had defined the right to marry as "the right to marry the person of one's choice," they understood that the classification at issue in effect imposed disparate treatment on the basis of sexual orientation.

With regard to the applicable level of scrutiny, the dissenters found that the sex-based classification was a quasi-suspect classification that ordinarily would be subject to intermediate-level scrutiny. ${ }^{278}$ They then made the pathbreaking finding that the sexual orientation-based classification was a suspect classification that ordinarily would be subject to strict scrutiny (based on the history of discrimination against gays and lesbians, the ability of gays and lesbians to perform and participate in society, and their political

\footnotetext{
271. Loving v. Virginia, 388 U.S. 1 (1967).

272. Hernandez, 855 N.E.2d at 29 (Kaye, C.J., dissenting) (quoting Loving, 388 U.S. at 8).

273. Id. at 22.

274. Id. at 29 .

275. Perez v. Sharp, 198 P.2d 17 (Cal. 1948) (the first case to strike down an antimiscegenation statute).

276. Hernandez, 855 N.E.2d at 29 (Kaye, C.J., dissenting) (quoting Perez, 198 P.2d at 20).

277. Id. (citation omitted).

278. Id.
} 
powerlessness). ${ }^{279}$ Yet, despite these findings, the dissenters said: “Although the classification challenged here should be analyzed using heightened scrutiny, it does not satisfy even rational-basis review, which requires that the classification 'rationally further a legitimate state interest." ${ }^{280}$ Like the plurality in Goodridge, then, the dissenters opted to apply a form of lowlevel scrutiny that was not toothless. ${ }^{281}$

Because the judges in Hernandez were applying two different forms of low-level scrutiny, they disagreed about how to state the issue in the case. In framing the issue under deferential low-level scrutiny, the concurring judge said: "[T]hese cases turn on whether the Legislature's decision to confine the institution of marriage to couples composed of one woman and one man is rationally related to any legitimate state interest." 282 By contrast, in framing the issue under non-deferential, low-level scrutiny, the dissenters said: "Correctly framed, the question before us is not whether the marriage statutes properly benefit those they are intended to benefit-any discriminatory classification does that-but whether there exists any legitimate basis for excluding those who are not covered by the law."283 Even more precisely, the dissenters said: "The relevant question here is ... whether the State's interests in recognizing or supporting opposite-sex marriages are rationally furthered by the exclusion." 284

The question of how to frame the issue under low-level scrutiny was so important in Hernandez because the defendant had articulated a justification for the State's marriage statute that was designed to counteract the Goodridge court's concern that the state's justifications for opposite-sex marriage (e.g., providing a favorable setting for procreation) actually served to stigmatize same-sex couples and their children. ${ }^{285}$ The defendant in Hernandez contended, and the plurality found, that the purpose of marriage is to promote responsible procreation. ${ }^{286}$ In other words, the plurality found that "the Legislature could rationally decide that, for the welfare of children, it is more important to promote stability, and to avoid instability, in opposite-sex than in same-sex relationships." 287 The plurality based its reasoning on the fact that, in the case of same-sex couples, parenthood is necessarily intended, while in the case of opposite-sex couples, parenthood

\footnotetext{
279. Id. at $27-29$.

280. Id. at 30 .

281. See supra notes 191-92 and accompanying text.

282. Hernandez, 855 N.E.2d at 20 (Graffeo, J., concurring).

283. Id. at 27 (Kaye, C.J., dissenting).

284. Id. at 30 .

285. See supra note 223 and accompanying text.

286. Hernandez, 855 N.E.2d at 7.

287. Id.
} 
may be the result of "accident or impulse." ${ }^{288}$ Consequently, as the plurality opinion concluded: "The Legislature could find that unstable relationships between people of the opposite sex present a greater danger that children will be born into or grow up in unstable homes than is the case with samesex couples, and thus that promoting stability in opposite-sex relationships will help children more."289

If the promotion of stability in opposite-sex relationships is a legitimate state objective, then (in the language of the concurring judge) it "is not irrational for the Legislature to provide an incentive for opposite-sex couples-for whom children may be conceived from casual, even momentary intimate relationships - to marry, create a family environment, and support their children." 290 Judge Graffeo recognized that "many samesex couples share these family objectives and are competently raising children in a stable environment." ${ }^{291}$ But she found that, because most samesex couples rely on assisted reproduction and adoption processes to have children, they simply are "not similarly situated" to opposite-sex couples with regard to the primary purpose of marriage, which is the promotion of responsible procreation. ${ }^{292}$

The dissenting judges acknowledged that the State has a legitimate interest in encouraging opposite-sex couples to marry before they have children. ${ }^{293}$ But, given the way in which the dissenters had framed the issue, they found that "the exclusion of gay men and lesbians from marriage in no way furthers this interest." 294 As Chief Judge Kaye pithily observed: "There are enough marriage licenses to go around for everyone." 295

In addition to considering the newly-minted argument that marriage promotes responsible procreation, the majority of the court and the dissenters in Hernandez all considered the long-standing argument that the definition of marriage is linked to procreation and the rearing of children. And they all recognized that the opposite-sex marriage classification is both over-inclusive and under-inclusive ${ }^{296}$ for the reasons first articulated by the court in Baker v. State. ${ }^{297}$ However, the majority of the court (in the

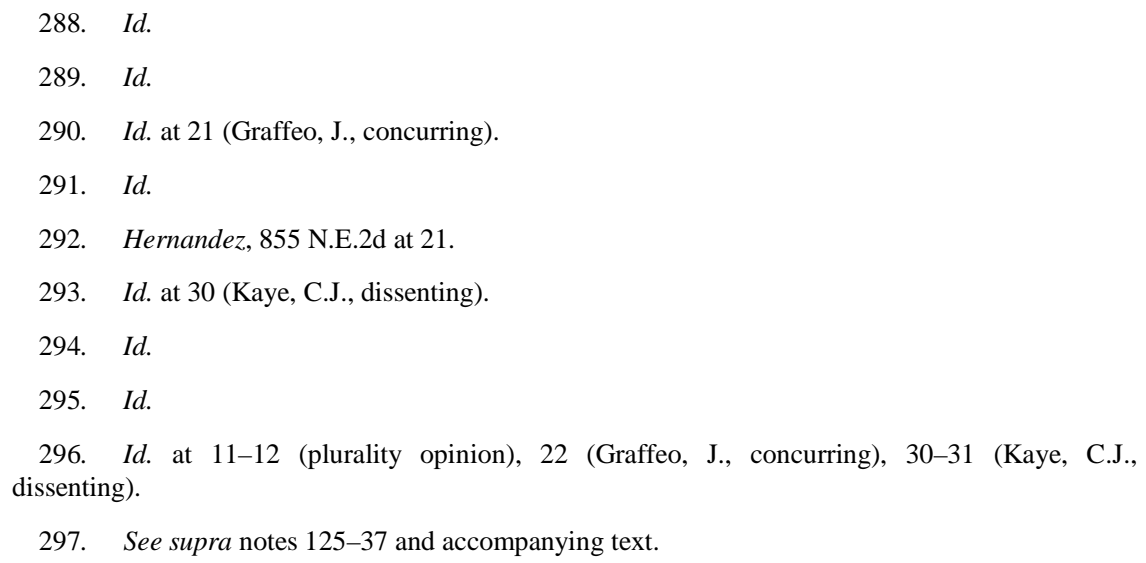


language of the concurring opinion) pointed out that "under rational basis review, the classification need not be perfectly precise or narrowly tailored." ${ }^{298}$ Rather, "all that is required is a reasonable connection between the classification and the interest at issue." ${ }^{299}$ A majority of the court held that the marriage statute met that test. ${ }^{300}$

The dissenters, by contrast, found that "no one rationally decides to have children because gays and lesbians are excluded from marriage.”301 They suggested alternative means to the end of promoting procreation, such as tax breaks to couples with children, subsidizing child care for those couples, and mandating generous family leave for parents. ${ }^{302}$ The dissenters also found that tradition could not in itself be a rational basis for the challenged exclusion because "the justification of 'tradition' does not explain the classification; it merely repeats it.”303

Hernandez is one of several state high court cases that explicitly rejected the court's reasoning in Goodridge. ${ }^{304}$ The New York Court of Appeals, like all of the other courts in this line of cases, took one huge step back. It refused to recognize any synergy whatsoever between liberty and equality, thereby replicating the reasoning of such state cases as Baker $v$. $N^{N e l s o n}{ }^{305}$ (even though it did not consider itself bound by the Supreme Court decision in Baker v. Nelson ${ }^{306}$ ). In applying very deferential low-level scrutiny and upholding the marriage statute, the court recognized not only the State's long-standing "marriage as procreation" argument, but also its newly-minted "responsible procreation" argument. Chief Judge Kaye, writing for the dissenters, closed her opinion with the following words: "I am confident that future generations will look back on today's decision as an unfortunate misstep.”307

\section{IN RE MARRIAGE CASES: FULl RECOGNITION OF THE SYNERGY BETWEEN LIBERTY AND EQUALITY}

The same-sex couples who filed consolidated complaints challenging

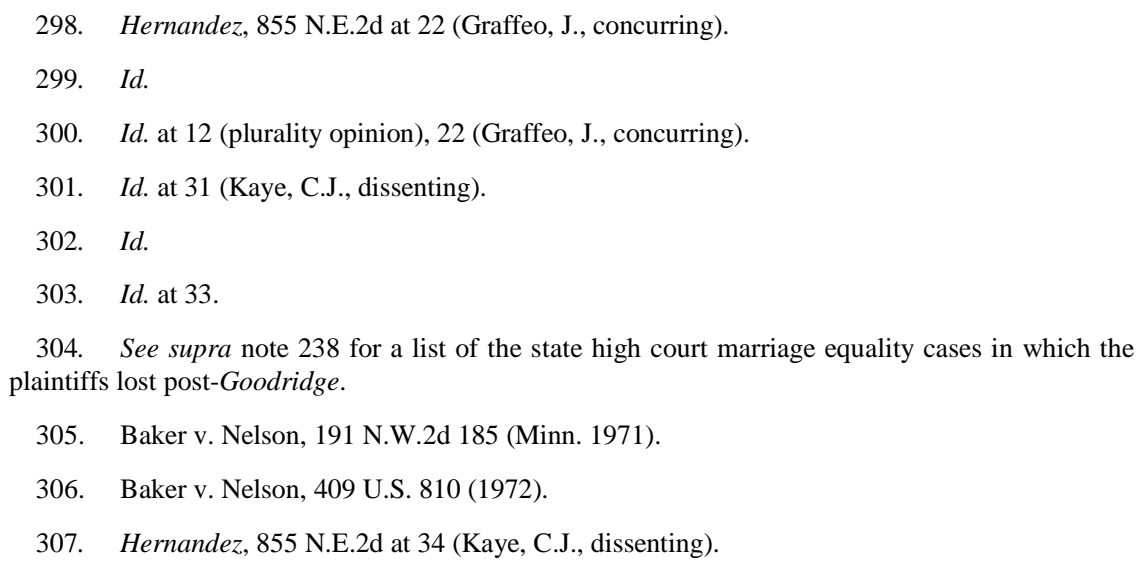


the State's opposite-sex marriage statutes in In re Marriage Cases ${ }^{308}$ (the California Marriage Cases) asserted both a liberty claim and an equality claim under the state constitution, ${ }^{309}$ hoping that the California Supreme Court would recognize the potential synergy between the two claims. The text of the state constitution provides: "A person may not be deprived of ... liberty... without due process of law or denied equal protection of the laws." ${ }^{110}$ The state constitution also explicitly provides that the rights guaranteed by the state constitution "are not dependent on those guaranteed by the United States Constitution.”311

California already had enacted comprehensive domestic partnership legislation, extending to same-sex couples virtually all of the benefits and imposing on them virtually all of the legal obligations that California law afforded to and imposed on married couples. ${ }^{312}$ The question, therefore, was "whether, under these circumstances, the failure to designate the official relationship of same-sex couples as marriage violates the California Constitution." 313 The plaintiffs were asking the court to extend the designation (or name) of marriage to same-sex couples. ${ }^{314}$

Chief Justice George wrote the majority opinion, and he turned first to the due process issue to determine whether the plaintiffs could successfully claim a fundamental liberty interest in the right to marry. All of the parties agreed that the right to marry constitutes a fundamental right under the state constitution. ${ }^{315}$ They disagreed, however, as to the nature of the right that the plaintiffs were claiming.

The defendants took the position that the plaintiffs were invoking a right to same-sex marriage. ${ }^{316}$ The plaintiffs responded that they were invoking the civil right "to join in marriage with the person of one's choice."'317 That was the due process right which was first recognized in Perez v. Sharp, ${ }^{318}$ the 1948 California Supreme Court decision striking

308. In re Marriage Cases, 183 P.3d 384 (Cal. 2008).

309. Id. at 403 (describing the same-sex couples who were among the several parties to the consolidated cases).

310. CAL. CONST. art. I, § 2.

311. Id. § 24 .

312. The domestic partnership legislation is described by the court. In re Marriage Cases, 183 P.3d at 397-98.

313. Id. at 398.

314. Id. at $452-53$.

315. Id. at 419 (noting that past California cases establish "beyond question" that the right to marry is a "fundamental right").

316. Id. at 420 .

317. Id. (quoting Perez v. Sharp, 198 P.2d 17, 19 (Cal. 1948)) (emphasis added in In re Marriage Cases, 183 P.3d 384).

318. Perez, 198 P.2d 17. 
down the State's anti-miscegenation statute. The plaintiffs noted that the court in Perez did not dismiss the plaintiffs' constitutional challenge on the ground that there was no due process right to interracial marriage. ${ }^{319}$ Instead, Perez extended the fundamental right to marry to interracial couples. ${ }^{320}$

The majority of the court agreed that the plaintiffs were not seeking to create a "new" constitutional right. Nor were they trying to "change" the existing institution of marriage. ${ }^{321}$ Rather, they were contending that, "properly interpreted, the state constitutional right to marry affords same-sex couples the same rights and benefits-accompanied by the same mutual responsibilities and obligations - as this constitutional right affords to opposite-sex couples.”322

Two of the dissenting judges took the position that the plaintiffs were indeed claiming "a new right to same-sex marriage." 323 Not surprisingly, they found that there is no deeply rooted tradition of same-sex marriage. ${ }^{324}$ The third dissenting judge said: "What is unique about this case is that plaintiffs seek both to join the institution of marriage and at the same time to alter its definition." ${ }^{325}$ She opined that the people are entitled to preserve the traditional name of marriage for opposite-sex couples. ${ }^{326}$

Because the majority of the court found that the plaintiffs were claiming a state constitutional right to marry the person of one's choice, the majority proceeded to examine the substantive content of the right. In an unprecedented opinion, the court held that the right was not merely a "negative" right, insulating a couple from interference by the State, but also a "'positive' right to have the state take... affirmative action to acknowledge and support the family unit." ${ }^{327}$ More specifically, the court said that the "positive" right to marry obligates the State "to take affirmative action to grant official, public recognition to the couple's relationship as a family." ${ }^{228}$ The court then concluded:

In light of the fundamental nature of the substantive rights embodied in the right to marry-and their central importance to an

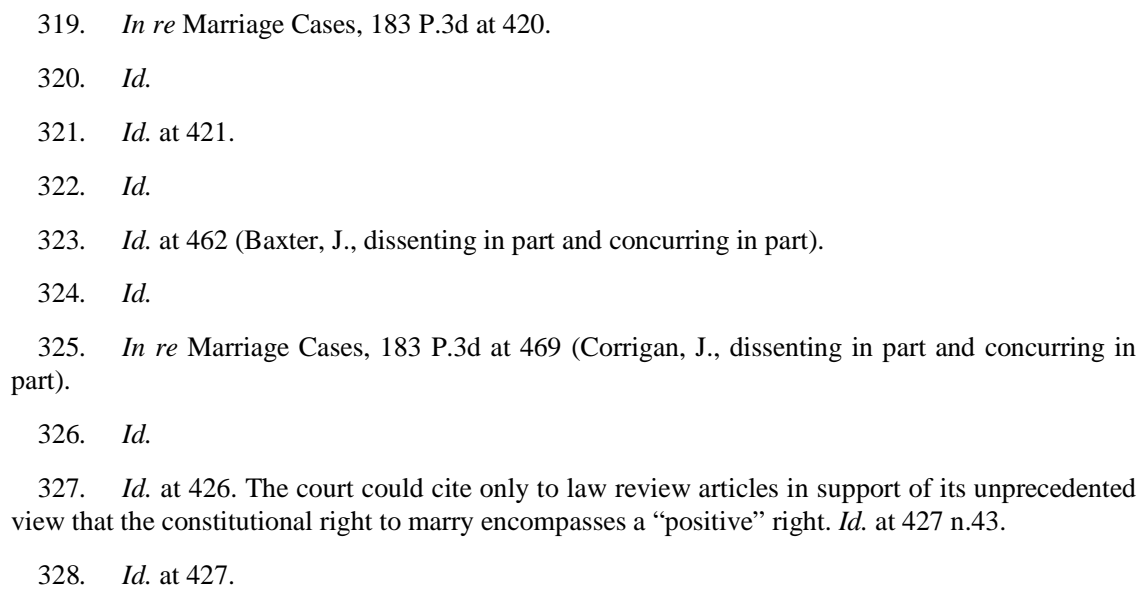


individual's opportunity to live a happy, meaningful, and satisfying life as a full member of society-the California Constitution properly must be interpreted to guarantee this basic civil right to all individuals and couples, without regard to their sexual orientation. ${ }^{329}$

This is the first moment of the full recognition of the synergy between liberty and equality in the California Marriage Cases. Because the court was looking at the right to marry through the lenses of both liberty and equality, just as the court had done in Goodridge v. Department of Public Health, ${ }^{330}$ it characterized the state constitutional right to marry as a "civil right" to marry the person of one's choice. ${ }^{331}$ It emphasized that the right to marry "is often of crucial significance to the individual's happiness and wellbeing." ${ }^{332}$ And then it extended the right to marry to all, regardless of sexual orientation. ${ }^{333}$ The court refused to let history and tradition define marriage. ${ }^{334}$ It also refused to link marriage to either procreation ${ }^{335}$ or responsible procreation, ${ }^{336}$ thereby adopting the reasoning of Chief Judge Kaye's dissenting opinion in Hernandez v. Robles. ${ }^{337}$

Chief Justice George then moved to the central question in the case: whether the failure to designate the official relationship of same-sex couples as "marriage" violated the state constitution's due process clause. The Attorney General asserted that no one has a constitutional right to the name of marriage, and that the State could assign a name other than marriage (such as registered domestic partnership or civil union) to all couples. ${ }^{338}$ The majority responded by saying:

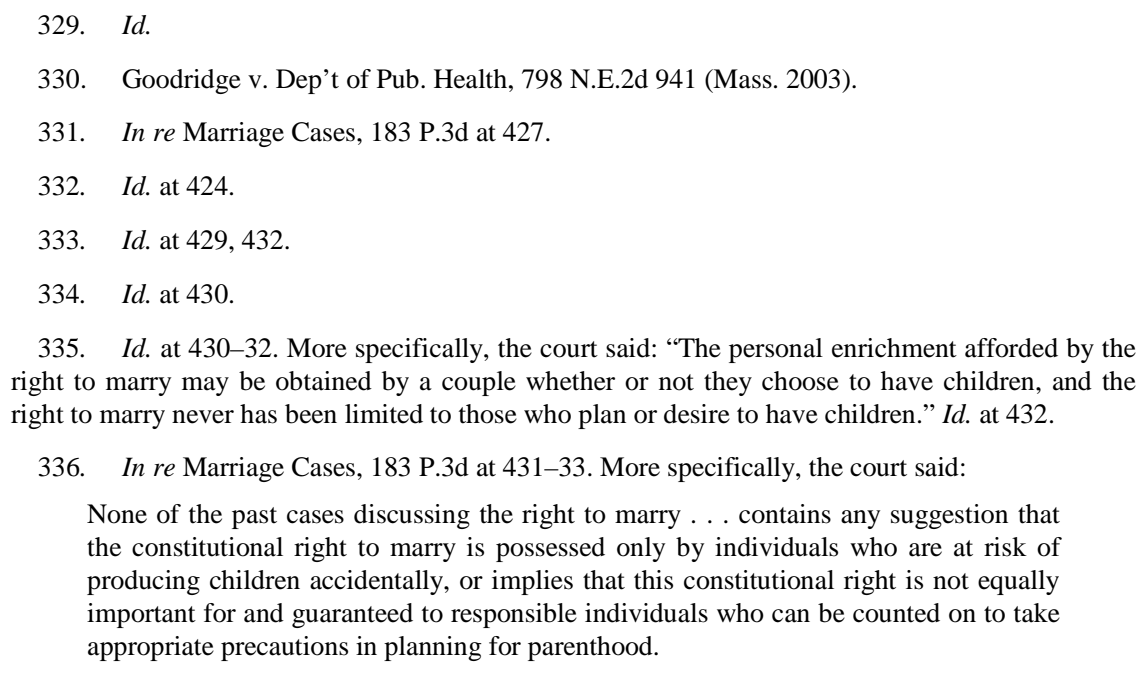

335. Id. at 430-32. More specifically, the court said: "The personal enrichment afforded by the right to marry may be obtained by a couple whether or not they choose to have children, and the right to marry never has been limited to those who plan or desire to have children.” Id. at 432.

336. In re Marriage Cases, 183 P.3d at 431-33. More specifically, the court said:

None of the past cases discussing the right to marry . . . contains any suggestion that the constitutional right to marry is possessed only by individuals who are at risk of producing children accidentally, or implies that this constitutional right is not equally important for and guaranteed to responsible individuals who can be counted on to take appropriate precautions in planning for parenthood.

Id. at 432 .

337. Hernandez v. Robles, 855 N.E.2d 1 (N.Y. 2006); see supra notes 293-95, 301-03 and accompanying text.

338. In re Marriage Cases, 183 P.3d at 434. 
Whether or not the name "marriage," in the abstract, is considered a core element of the state constitutional right to marry, one of the core elements of this fundamental right is the right of same-sex couples to have their official family relationship accorded the same dignity, respect, and stature as that accorded to all other officially recognized family relationships. ${ }^{339}$

The court then held that, because the state was denying the name "marriage" to same-sex couples while granting that "historic and highly respected" name to opposite-sex couples, the state was "potentially impinging upon the state constitutional right of same-sex couples to marry," thereby triggering strict scrutiny. ${ }^{340}$

This is the second moment of the full recognition of the synergy between liberty and equality in the California Marriage Cases. The court was faced with the question of whether the name "marriage" is part of the constitutional right to marry under the due process clause. It answered the question by reference to principles of equality. It found that one of the core elements of the constitutional right to marry is the right to have one's official family relationship accorded equal dignity and respect.

With regard to the equal protection clause, the plaintiffs claimed that the opposite-sex marriage statutes should be subjected to strict scrutiny because they contained either a sex-based classification or a sexual orientation-based classification. ${ }^{341}$ The dissenting judges would have held that it was unnecessary to consider how to characterize the classification at issue because same-sex couples are not similarly situated to opposite-sex couples for purposes of marriage. ${ }^{342}$ The court disagreed, finding that samesex couples are similarly situated to opposite-sex couples because "[b]oth groups at issue consist of pairs of individuals who wish to enter into a formal, legally binding and officially recognized, long-term family relationship." ${ }^{343}$

This is the third moment of the full recognition of the synergy between liberty and equality in the California Marriage Cases. The court had characterized the constitutional right to marry as the right to marry the person of one's choice. It had refused to link marriage to either procreation or responsible procreation. Instead, it had linked marriage to happiness. Moreover, the court had defined the constitutional right to marry as the right to have one's official family relationship accorded equal dignity and respect. Therefore, the court was in a position to rule that same-sex couples are

\footnotetext{
339. Id.

340. Id. at 434-35.

341. Id. at 436

342. Id. at 464 (Baxter, J., dissenting in part and concurring in part), 470 (Corrigan, J., dissenting in part and concurring in part).

343. Id. at 435 n.54.
} 
similarly situated to opposite-sex couples for purposes of marriage.

The majority held that the opposite-sex marriage statutes contained a facial sex-based classification, but that the classification was subject to the equal application defense. ${ }^{344}$ It distinguished Perez and Loving $v$. Virginia ${ }^{345}$ on the ground that both cases involved facial racial classifications where there was evidence of a legislative purpose to maintain white supremacy. ${ }^{346}$ It also observed that most of the prior state court marriage equality cases had come to the same conclusion. ${ }^{347}$

The majority next considered whether the opposite-sex marriage statutes contained a sexual orientation-based classification. The court acknowledged that there was no facial sexual orientation-based classification. ${ }^{348}$ Then it said: "In our view, the statutory provisions restricting marriage to a man and a woman cannot be understood as having merely a disparate impact on gay persons, but instead properly must be viewed as directly classifying and prescribing distinct treatment on the basis of sexual orientation.”349

This is the fourth moment of the full recognition of the synergy between liberty and equality in the California Marriage Cases. Because the court had defined marriage as the civil right to marry the person of one's choice, it understood that gays and lesbians would want to marry someone of the same sex. A statute restricting marriage to persons of opposite sexes would place marriage "outside the reach of couples of the same sex," thereby unquestionably treating them differently from opposite-sex couples on the basis of sexual orientation. ${ }^{350}$

The court then turned to the question of the applicable level of scrutiny for sexual orientation-based classifications. The issue was whether to apply low-level scrutiny or strict scrutiny. The court came to the unprecedented conclusion that sexual orientation is a suspect classification subject to strict scrutiny (based on proof of the history of discrimination, the ability of gays and lesbians to perform or contribute to society, and their historical political powerlessness). ${ }^{351}$

The final issue under the equal protection clause was whether the marriage statutes impinged upon a "fundamental, constitutionally protected

\footnotetext{
344. In re Marriage Cases, 183 P.3d at 436.

345. Loving v. Virginia, 388 U.S. 1 (1967).

346. In re Marriage Cases, 183 P.3d at 437.

347. Id. at 438 n.57.

348. Id. at 440.

349. Id. at 441.

350. Id.

351. In re Marriage Cases, 183 P.3d at 441-44. The court did not consider whether sexual orientation is a quasi-suspect classification because the California courts recognize only two tiers of scrutiny under the state's equal protection clause. Id. at 435-36.
} 
privacy interest." ${ }^{352}$ The court found that, by restricting same-sex couples to the separate institution of domestic partnerships, and by denying them access to marriage, the legislature had impinged upon the right of same-sex couples to have their family relationships accorded equal respect and dignity. ${ }^{353}$ The distinction in nomenclature was a "mark of second-class citizenship." ${ }^{354}$ For this additional reason, the court held that the marriage statutes ought to be subject to strict scrutiny under the fundamental interest strand of the equal protection clause. This is the fifth moment of the full recognition of the synergy between liberty and equality in the California Marriage Cases. The court's opinion demonstrates that the fundamental interest strand of equal protection analysis is a particularly effective theory for examining an issue stereoscopically.

When the court applied strict scrutiny to the opposite-sex marriage statutes, it held that they violated the state constitution. ${ }^{355}$ The Attorney General chose to focus his attention exclusively on the justification of tradition, stating that "marriage continues to apply only to a relationship between opposite-sex couples in the overwhelming majority of jurisdictions in the United States and around the world.”356 The court agreed with Chief Judge Kaye that this limitation on marriage was not necessary to preserve the rights and benefits of marriage traditionally enjoyed by opposite-sex couples: "There are enough marriage licenses to go around for everyone."357 Moreover, the court found that excluding same-sex couples from marriage inflicts a "real and appreciable harm upon same-sex couples and their children." 358 Consequently, when the court turned to a consideration of what would be an appropriate remedy, the court chose to extend the designation of marriage to same-sex couples. ${ }^{359}$

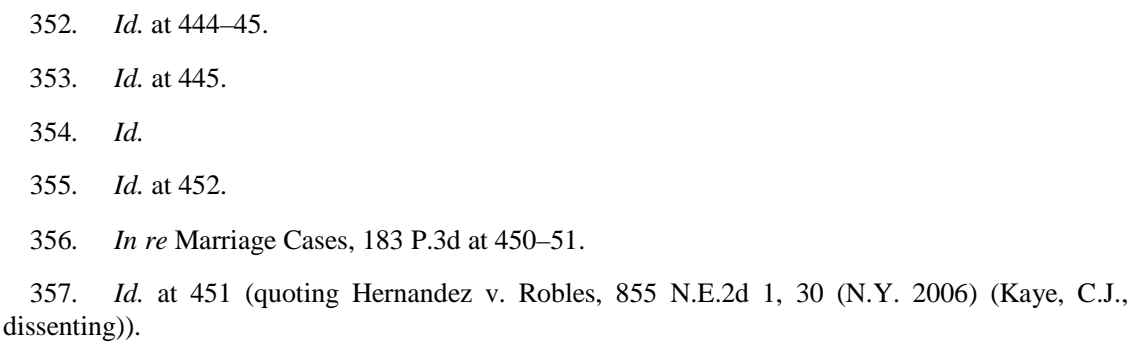

358. Id. at 452.

359. Id. at 452-53. In another case holding that a legislative designation of an alternative status for same-sex couples (civil unions) was unconstitutional, the Connecticut Supreme Court agreed with the California Supreme Court regarding the appropriate remedy. Kerrigan v. Comm'r of Pub. Health, 957 A.2d 407, 480 (Conn. 2008) ("[T]he traditional definition of marriage . . . must be expanded to include [same-sex] couples.”). In November of 2008, the people of California passed Proposition 8, which added the following language to the California Constitution: "Only marriage between a man and a woman is valid or recognized in California." CAL. CONST. art. I, § 7.5 (2008). The California Supreme Court upheld the validity of Proposition 8 on the theory that it was "a permissible constitutional amendment (rather than an impermissible constitutional revision)." Strauss v. Horton, 207 P.3d 48, 122 (Cal. 2009). On the other hand, the court ruled that Proposition 8 would not apply retroactively to void any of the marriages validly entered into before the passage of 
The California Supreme Court was the first state high court to hold that the right to marry is a fundamental right that triggers strict scrutiny not only under the due process clause, but also under the fundamental interest strand of the equal protection clause. Additionally, it was the first state high court to hold that a sexual orientation-based classification is a suspect classification that must be subjected to strict scrutiny under the equal protection clause. The court was able to formulate these unprecedented holdings because it fully recognized the synergy between liberty and equality.

\section{VARNUM V. BRIEN: BUILDING ON THE FULL RECOGNITION OF THE SYNERGY BETWEEN LIBERTY AND EQUALITY}

The six same-sex couples who filed a complaint in Varnum v. Brien ${ }^{360}$ challenged Iowa's opposite-sex marriage statute after the Polk County recorder (Timothy Brien) refused to issue marriage licenses to them. ${ }^{361}$ They asserted both due process and equal protection claims under the state constitution. ${ }^{362}$ The Iowa Supreme Court observed that generally it views "the federal and state equal protection clauses as identical in scope, import, and purpose." 363 At the same time, the court noted that "we have jealously guarded our right to 'employ a different analytical framework' under the state equal protection clause as well as to independently apply the federally formulated principles." 364 By way of example, the court cited to a long line of Iowa Supreme Court cases going back to 1839 in which the court had recognized the constitutional rights of slaves, racial minorities, and women years before the United States Supreme Court had recognized comparable rights under the Federal Constitution. ${ }^{365}$

In Varnum, the Iowa Supreme Court issued the first unanimous opinion in a marriage equality case, with Justice Cady writing for the court. It is an elegant opinion which builds upon the California Supreme Court's full recognition of the synergy between liberty and equality. Justice Cady opened his opinion with a quotation from the state motto: "Our liberties we prize and our rights we will maintain." 366 He observed that the "primary

\footnotetext{
Proposition 8. Id. Propostion 8 is now being challenged in federal court under the Federal Constitution. See Perry v. Schwarzenegger, No. CV09-2292 (N.D. Cal. filed May 22, 2009), available at http://www.equalrightsfoundation.org/legal-filings/plaintiffs-filed-complaint/.

360. Varnum v. Brien, 763 N.W.2d 862 (Iowa 2009).

361. Id. at 872.

362. Id. at 873.

363. Id. at 878 n.6.

364. Id.

365. Id. at 877.

366. Varnum, 763 N.W.2d at 872 n.1.
} 
constitutional principle at the heart of this case is the doctrine of equal protection," 367 and he found it unnecessary to consider the plaintiffs' other claims. ${ }^{368}$ Nevertheless, his discussion of equal protection is infused with references to the fundamental right to marry, as defined by the California Supreme Court. ${ }^{369}$ Therefore, although his opinion initially appears to be based exclusively on the state constitution's equal protection clause, nevertheless, it is an exquisite example of an opinion that fully recognizes the synergy between liberty and equality.

Justice Cady opened his discussion of the equal protection issue by stating: "This issue comes to us with the same importance as our landmark cases of the past." ${ }^{370}$ Next, he observed that the same-sex marriage debate before the court was "part of a strong national dialogue centered on a fundamental, deep-seated, traditional institution that has excluded, by state action, a particular class of Iowans." " equal protection issue in the case: "How can a state premised on the constitutional principle of equal protection justify exclusion of a class of Iowans from civil marriage?”372

The court first considered the threshold issue under the State's equal protection clause - whether the plaintiffs were similarly situated to oppositesex couples. The defendant sought to undermine the plaintiffs' equal protection claim by asserting that the plaintiffs "are not similarly situated to opposite-sex couples... because the plaintiffs cannot 'procreate naturally." " 373 Put another way, the defendant argued that the statute treated dissimilar persons differently. In response, the court explained that, when analyzing the similarly situated issue, it would not "simply look at the trait used by the legislature to define a classification under a statute and conclude that a person without that trait is not similarly situated to persons with the trait." ${ }^{374}$ Since all members of any class are similarly situated in this respect, the court observed that " "any classification whatsoever would be reasonable by this test." "375 Instead, the court held that "the equal protection guarantee requires that laws treat all those who are similarly situated with respect to

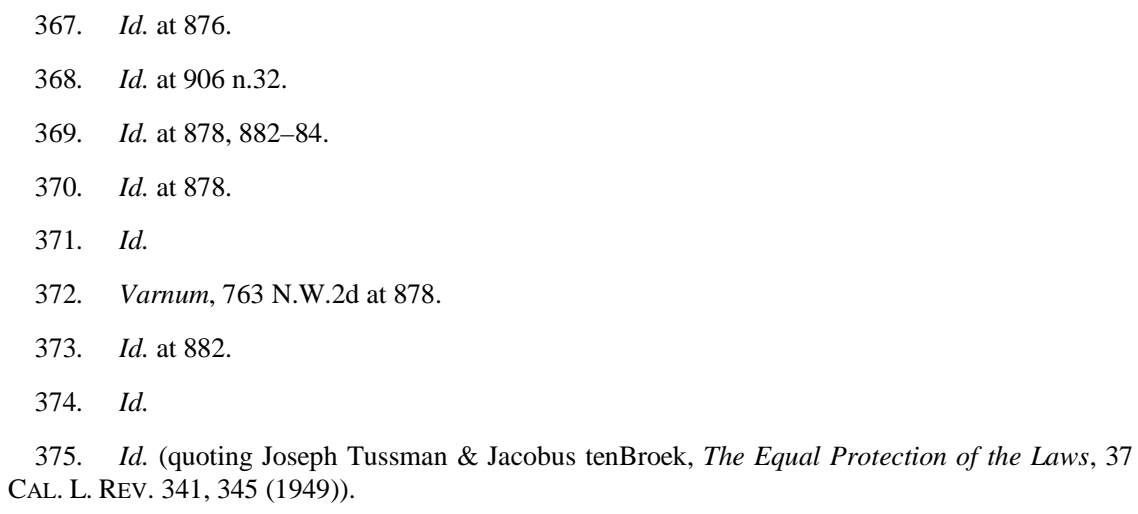


the purposes of the law alike.”376

The court then explained that the plaintiffs were in "committed and loving relationships, many raising families, just like heterosexual couples," thereby emphasizing the fact that one of the reasons for marriage is to promote "comfort and happiness." 377 Moreover, the court found that officially recognizing their status would provide "an institutional basis for defining their fundamental relational rights and responsibilities, just as it does for heterosexual couples." ${ }^{378}$ In short, the court concluded that, for purposes of Iowa's marriage laws, "which are designed to bring a sense of order to the legal relationships of committed couples and their families in myriad ways," the plaintiffs were "similarly situated in every important respect, but for their sexual orientation." ${ }^{379}$ Therefore, the court refused to recognize the defendant's threshold challenge to the application of the equal protection clause.

This is the first moment when the court recognized the synergy between liberty and equality in Varnum. It found that procreation is not the sine qua non of marriage. Instead, it found that marriage is intended to promote the comfort and happiness of committed couples and to bring order and stability to their relational rights and responsibilities as well as to their families. Consequently, the court concluded that same-sex couples are similarly situated to opposite-sex couples with respect to the purposes of marriage.

The next issue before the Iowa Supreme Court was the nature of the classification. The court below had held that the opposite-sex marriage statute classified on the basis of sex, but Justice Cady took the position that the statute actually classified on the basis of sexual orientation. ${ }^{380} \mathrm{He}$ recognized that the statute did not contain a facial sexual orientation-based classification. ${ }^{381}$ Nevertheless, he rejected the defendant's argument that the statute had only a disparate impact upon gay and lesbian people. ${ }^{382}$ Instead, he characterized the statute as containing an implicit sexual orientationbased classification that resulted in disparate treatment. ${ }^{383}$

Justice Cady explained his position by describing the plaintiffs as individuals who are "sexually and romantically attracted to members of their own sex." ${ }^{384}$ He then observed that, when "[v]iewed in the complete context

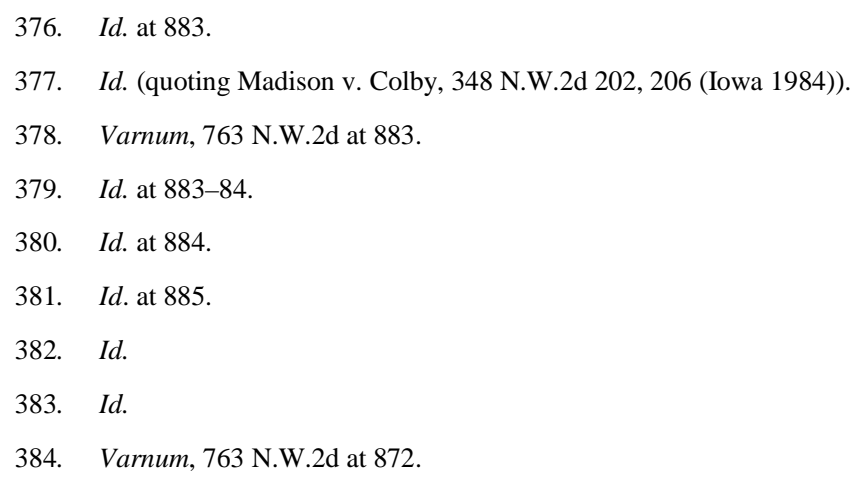


of marriage, including intimacy, civil marriage with a person of the opposite sex is as unappealing to a gay or lesbian person as civil marriage with a person of the same sex is to a heterosexual." 385 Thus, he concluded, "the right of a gay or lesbian person under the marriage statute to enter into a civil marriage only with a person of the opposite sex is no right at all."386 Instead, a gay or lesbian person can only gain the same rights under the statute as a heterosexual "by negating the very trait that defines gay and lesbian people as a class - their sexual orientation," meaning that the statute "differentiates implicitly" on the basis of sexual orientation. ${ }^{387}$

This is the second moment when the Iowa Supreme Court recognized the synergy between liberty and equality in Varnum. Because the court had found that marriage is intended to promote the comfort and happiness of committed couples, and because it understood that gay and lesbian persons are sexually and romantically attracted to members of their own sex, the court realized that a gay or lesbian person would not want to marry a person of the opposite sex. Therefore, it ruled that the classification at issue was in effect a sexual orientation-based classification.

The court then turned to the question of the applicable level of scrutiny for sexual orientation-based classifications. It took the position that such classifications are quasi-suspect classifications subject to intermediate scrutiny (based on the history of discrimination, the ability of gays and lesbians to contribute to society, the immutability of sexual orientation, and the historical political powerlessness of gay and lesbian people). ${ }^{388}$ When the court applied heightened scrutiny, it found that the statute violated the equal protection clause because it was both over-inclusive and underinclusive for all of the reasons first set forth by the court in Baker v. State. ${ }^{389}$

Finally, Justice Cady considered the appropriate remedy, noting that courts in other jurisdictions either had allowed the state legislature to create an alternative status for same-sex couples or had extended marriage to them. ${ }^{390}$ The court refused to authorize the Iowa legislature to create an alternative status (such as civil unions), stating: "This record, our own independent research, and the appropriate equal protection analysis do not suggest the existence of a justification for such a legislative classification that substantially furthers any governmental objective." ${ }^{391}$ Consequently, the

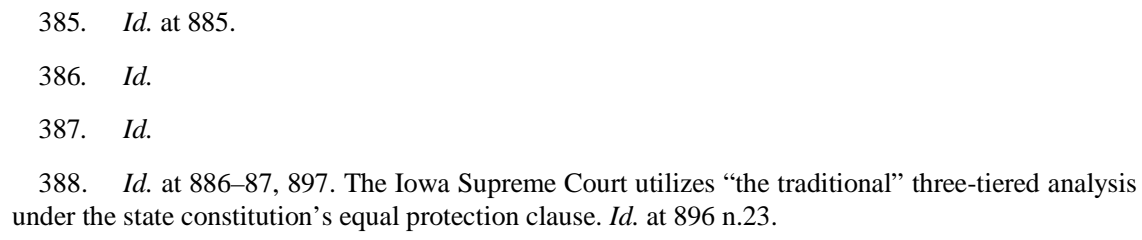

389. Baker v. State, 744 A.2d 864 (Vt. 1999); Varnum, 763 N.W.2d at 900-02; see also supra notes $125-37$ and accompanying text.

390. Varnum, 763 N.W.2d at 906-07.

391. Id. 
court held that "the language in [the Iowa marriage statute] limiting civil marriage to a man and a woman must be stricken from the statute, and the remaining statutory language must be interpreted and applied in a manner allowing gay and lesbian people full access to the institution of civil marriage.”392

Because the court throughout its opinion had examined the equal protection challenge stereoscopically through the lenses of liberty and equality, it understood when it came to the remedial phase of the case that the plaintiffs were entitled to both the status of marriage and the statutory benefits of marriage. The plaintiffs could not be treated as second-class citizens by confining them to an alternative status, such as civil unions. Instead, they were entitled to an inclusive remedy that would afford them full access to the institution of civil marriage.

\section{CONCLUSION}

This Article has examined selected marriage cases brought by same-sex couples in state courts under state constitutions in order to understand the role played by liberty and equality in this one segment of gay rights litigation. It is the thesis of this Article that, when gay rights litigators and state courts have considered the two constitutional claims independently of each other, neither claim standing alone has been strong enough to provide a basis for extending the institution of civil marriage to same-sex couples. But, when gay rights litigators and state courts have focused on both claims simultaneously, looking at the institution of marriage stereoscopically, the synergistic effect of the interplay between the two claims gradually has enabled the courts to rethink the fundamental question of whether marriage is an exclusive institution for opposite-sex couples only. In some of the cases under review, after the courts have looked at the institution of marriage through the lenses of liberty and equality simultaneously, they have come to the twin conclusions that the state's opposite-sex marriage statute is unconstitutional and that same-sex couples must have full access to the institution of civil marriage. These are the decisions that represent the culmination of the synergistic evolution of liberty and equality in the state court marriage cases to date. They are also the decisions that may provide a model for state and federal court marriage litigation in the future.

392. Id. at 907. 